Canadian

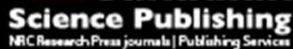

Canadian Geotechnical Journal Revue canadienne de géotechnique

\title{
An empirical method for predicting post-construction settlement of concrete face rockfill dams
}

\begin{tabular}{|r|l|}
\hline Journal: & Canadian Geotechnical Journal \\
\hline Manuscript ID & cgj-2016-0193.R1 \\
\hline Manuscript Type: & Article \\
\hline Date Submitted by the Author: & 22-Sep-2016 \\
\hline Complete List of Authors: & $\begin{array}{l}\text { Kermani, Mohammad; Université Laval, Civil and Water Engineering } \\
\text { Konrad, Jean-Mari; Université Laval, } \\
\text { Smith, Marc; Hydro-Quebec, }\end{array}$ \\
\hline Keyword: & CFRD, rockfill, time-dependent, settlement prediction, empirical \\
\hline
\end{tabular}

SCHOLARONE ${ }^{m}$

Manuscripts 


\section{An empirical method for predicting post-construction settlement of concrete face rockfill dams}

\section{Mohammad Kermani ${ }^{1}$, Jean-Marie Konrad ${ }^{2}$, Marc Smith ${ }^{3}$}

1. Laval University; 1065, avenue de la Médecine, Pavillon Adrien-Pouliot, local 2913

Université Laval, Québec (Québec), G1V 0A6, CANADA;

Email: kermani.mhmmd@gmail.com

Telephone: +1 (514) 2244525

(Corresponding author)

2. Laval University; 1065, avenue de la Médecine, Pavillon Adrien-Pouliot, local 2912-B

Université Laval, Québec (Québec), G1V 0A6, CANADA;

Email: jean-marie.konrad@gci.ulaval.ca

3. Hydro-Quebecc; 75 René-Lévesque Blvd. West, Montréal, Québec H2Z 1A4

Email: Smith.marc@hydro.qc.ca 


\begin{abstract}
:
In this study, employing a database of 19 concrete face rockfill dam (CFRD) cases, two prediction methods for post-construction settlement of CFRDs are presented. In the first method, post-construction settlements are estimated using height of the embankment. In the second method, characterization of the stress-strain behavior of the compacted rockfill layers during construction allows prediction of the subsequent stress-strain-time behavior of the embankment. Knowledge of rock particles strength is necessary in both methods. In the presented methods, settlements are estimated separately for each of the three life-cycle phases: before, during and after impoundment. The presented results show that, in addition to addressing some limitations of previous methods, the proposed approach is precise and highly practical. It also allows a better understanding of rockfill deformation mechanisms. Apart from using this method for predictive purposes, the presented graphs can be used to distinguish unexpected settlement behavior of a CFRD during its post-construction lifespan.
\end{abstract}

Keywords: CFRD, rockfill, time-dependent, post-construction, settlement, prediction.

\title{
Résumé:
}

Dans cette étude, à partir d'une base de données de 19 barrages en enrochement avec un masque amont en béton (CFRD), deux méthodes de prédiction de tassement post-construction de CFRDs sont présentés. Dans la première méthode, les tassements post-construction sont estimés en fonction de la hauteur du remblai. Dans la deuxième méthode, le comportement contrainte-déformation de l'enrochement des remblais lors de la construction permet de prédire le comportement contrainte-déformation-temps subséquent du barrage. La connaissance de la résistance des particules rocheuses est nécessaire avec les deux méthodes. Pour ces deux méthodes, les tassements en crête sont estimées séparément pour chacune des trois phases du cycle de vie d'un barrage: avant, pendant et après la mise en eau du réservoir. Les résultats présentés montrent qu'en plus de surmonter les difficultés reliées aux méthodes actuelles, les approches proposées sont précises et très pratiques. Elles permettent, également, une meilleure 
compréhension des mécanismes de déformation de l'enrochement. En plus de servir d'outil prédictif des tassements, les relations présentées peuvent être utilisées afin de détecter un comportement atypique d'un CFRD au cours de sa durée de vie. 


\section{Introduction}

The origin of rockfill dams can be traced back to the mining region of California Sierras, in the 1850s. Rockfill dams were of the impervious face type, constructed by dumped rockfill, until earth core dams began to be developed in about 1940 . The period from 1850 to 1940 is called the early period by Cooke (1984). The dumped (in $18 \mathrm{~m}-60 \mathrm{~m}$ lifts) concrete face rockfill dams (CFRD) performed safely, but the leakage problem became more serious as dams became higher, due to high compressibility of dumped rockfill. During the years 1940 to 1970 (called transition period by Cooke 1984) earth core rockfill dams became more popular due to higher flexibility of earth materials, and consequently more compatibility with dumped rockfill. Additionally, mostly during the period 1955-1965, a transition developed to the use of sluiced rockfill in thinner layers of 3-3.6 m subsequently compacted by construction truck and dozer traffic. The period after 1970, when compacted and sluiced rockfill was used in construction of rockfill dams of both concrete face and earth core type is called the modern period (ICOLD 2010). This study addresses the post-construction behavior of CFRDs constructed during the modern period.

CFRDs are widely used because of their cost-effectiveness and the similarity of their constituent materials. Like other types of rockfill embankments, CFRDs are not highly prone to instability. However, attention must be paid to their settlement as excessive displacement may cause cracking of the concrete face, which can result in severe leakage. Some examples of modern CFRDs constructed in the $21^{\text {st }}$ century which suffered severe leakage are Campos Novos and Barra Grande dams in Brazil, and the Mohale dam in Lesotho (Marulanda 2013).

Rockfill consists of rock particles having a large diameter (average size of at least 5 centimeters and maximum size of up to 2 meters) with a variety of particle sizes, shapes and minerals. As a consequence, full scale experimental study of rockfill material is almost impossible. Scale effects are shown to influence the representativeness of the results of laboratory experiments on rockfill (Marachi et al. 1969; Marsal 1973; Ramon et al. 2008; Alonso et al. 2012). Also, limited laboratory samples are not perfect 
representations of in-situ conditions considering the variety of materials used in different zones or even in a single zone of a dam. When studying long-term deformations, load application periods are also limited in the laboratory compared to reality. Moreover, no laboratory experiment can apply the same stress path to the sample as in the field.

Numerical models must be calibrated using laboratory experiments, which are prone to the abovementioned uncertainties. Also, there are uncertainties about using concepts from classical soil mechanics to evaluate the strength and deformation behavior of rockfill. Accordingly, so far, the design of rockfill dams has been mostly based on engineering judgment and experience.

There are several studies in the literature in which settlements of different typical rockfill embankments, including CFRDs, are compared in order to find a settlement prediction method. These studies are categorized into two groups. The first category consists in studies in which an implicit equation is suggested to calculate dam crest settlement. These equations are mainly of three types: logarithmic strain versus time (Sowers et al. 1965), power type (Soydemir and Kjaernsli 1979), or strain rate versus time (Parkin 1977) relationships.

The second category includes more recent studies, which suggest a qualitative judgment procedure to predict settlements. For instance, Clements (1984), conducting a study on post construction crest deformations of 68 rockfill dams, suggested predicting the crest settlements by comparing the dam with previously monitored dams with similar characteristics. The major drawback of this approach is that there are many influencing factors which can lead to a high degree of subjectivity. Milligan and Coyne (2005) prepared a database of 95 rockfill dams, with which they questioned the statements of previous researchers who claimed that rockfill dams settle a maximum $0.02 \%$ of their height per year after three years from the end of construction. They also concluded that because of the considerable amount of variables involved, it is unreliable to use the empirical formulas to predict deformations.

One of the most comprehensive and practical studies on post-construction settlement of CFRDs was 
carried out by Hunter and Fell (2002). They suggested some empirical methods to predict the rockfill modulus during construction, crest settlement due to impoundment and the rate of time-dependent crest settlement. They divided the post-construction deformations into two parts: time dependent crest settlements and crest settlement under stresses from first filling. For the post-construction settlements, they suggested that the time datum begin at the end of main rockfill zone construction. The crest settlement attributed to first filling takes place from the beginning of impoundment to a limited time after the end of impoundment. The two components are shown in Fig. 1 for the Bastyan rockfill dam. Hunter and Fell (2002) suggested that the rate of long-term crest settlement, $\alpha$, as well as the crest settlement attributed to first filling can be estimated considering dam height, the rockfill placement method and the unconfined compressive strength (UCS) of rockfill materials.

In this study, first, the empirical method for prediction of the post-construction settlements of concrete face rockfill dams (CFRDs) by (Hunter and Fell 2002) is modified by changing the time datum for the settlements after impoundment and considering different relative crest settlement rates for the periods before and after impoundment. Also, using a data base of 19 CFRD cases, a novel prediction method is presented using behavior of the embankment during construction. Then, comparing the relative settlement rates before and after impoundment, some aspects of long-term mechanical behavior of compacted rockfill material are put into perspective. Finally, an example application of the prediction methods is presented.

\section{Post-construction crest settlement prediction methods}

In the method presented here, it is assumed that the post-construction deformations take place in three phases: 1) time-dependent deformations after construction and before impoundment; 2) deformations during impoundment; and 3) time-dependent deformations after impoundment (Fig. 2.a). The settlements attributed to each phase are calculated separately.

For the time-dependent deformations after construction and before impoundment, the time datum is the 
end of construction. However, for the long-term crest settlements after impoundment, the time datum is the end of impoundment. This has two major advantages.

First, since the stresses inside the dam body change during the impoundment period and stay almost constant after the end of impoundment, it is reasonable that the time datum for the time-dependent deformations be the end of impoundment. Therefore, the settlement rate values $\left(\alpha_{2}\right.$ in Fig. $\left.2 . b\right)$ are more representative values, when comparing to $\alpha$ values in Fig. 1. This is the same concept as setting the time to zero for every load increment within an oedometer test.

Second, as it is shown in Fig. 2.a for Bastyan dam and observed in almost all of the case studies, it takes almost one year after the impoundment for the settlement data points to fall onto a line in semi-log scale. In the method presented by Hunter and Fell (2002), it is assumed that deformations that take place from the beginning of impoundment to the end of this time lag attribute to the effect of first filling. Also, no indication was given how the length of this delay can be calculated. Because of the nature of graphs drawn by logarithmic scale, this delay changes the crest settlement calculations significantly. Therefore, making settlement predictions using the method presented by Hunter and Fell (2002) is complicated.

On the contrary, in this study, by changing the time datum, the data points after the impoundment will lie onto a line in semi-log scale almost right after the end of impoundment (Fig. 2.b). Therefore, if the time datum is set to the time after which stresses remain almost constant in the embankment, i.e. end of impoundment, the settlement of the crest will fall onto a line in semi-log graph. This is in-line with the generally observed behavior of rockfill materials, which show logarithmic creep deformations with time (e.g., Sowers et al. 1965; Marsal 1973; Clements 1981; Alonso et al. 2005). It also allows using this approach to predict the post-construction deformations. 
In order to develop a prediction method, for the two time-dependent phases, the crest settlement rates per height of embankment (relative crest settlement rates, $\alpha_{1}$ and $\alpha_{2}$ in Fig. 2.a and Fig. 2.b, respectively), and for the reservoir filling phase the maximum crest settlement attributed to impoundment per height of the embankment (relative crest settlement attributed to impoundment, $S_{\text {imp }}$ in Fig. 2.a) are considered. The crest settlements, as well as dam heights, were normally measured at cross sectional locations with maximum height for each case. For all the three phases, the crest settlement is shown to be predictable, knowing unconfined compressive strength of intact rock and one of the following: dam height, or the rockfill mechanical behavior during construction. To take strength of rockfill particles into account, the data are presented separately for the dams constructed of high strength rockfill zones, or, of very high strength rockfill zones as classified by the Australian code (Table 1). This means that the rockfill used in the construction of the dam has been extracted from quarries, where the intact rock has been characterized to have the average strength classified as high or very high strength within Table 1.

In this study, no case with dumped rockfill was studied because of the lack of quality and quantity of data in such cases, and the point that the mechanical behavior of dumped rockfill is considered to differ entirely form compacted rockfill. Therefore, here, the placement method is not directly considered as an influencing factor. Also, since the rockfill used in all of the studied cases is of quarried origin, the influence of shape of particles could not be studied.

The database used in this study is mostly adapted from Hunter and Fell (2002), but also from (Kermani 2016). Nevertheless, the cases with high quality data on post-construction deformations as well as behavior during construction are chosen. Table 2 presents a summary of properties of embankments as well as the rockfill used in case studies. The CRFD cases constructed of very high strength rockfill materials (above) are separated with a line from the cases of high strength rockfill (below). 
A typical cross section of a modern CFRD is shown in Fig. 3. The main rockfill zones are Zones 3B and 3C. Usually, rockfill is coarser and is placed in thicker layers in zone 3C compared to zone 3B (layer thickness and maximum rock diameter are usually limited to $1 \mathrm{~m}$ for Zone 3B, and $2 \mathrm{~m}$ for Zone 3C). The central variable zone in this figure shows variations in the size of these two zones in design practice around the world. Zones $1 \mathrm{~A}$ and $1 \mathrm{~B}$ are earthfill zones, and Zones $2 \mathrm{~B}$ and $3 \mathrm{~A}$ support the concrete face slab. The data presented in Table 2 mostly associate with rockfill placed in zone 3B and also in Zone 3C.

\section{Post-construction crest settlement prediction method using dam height and rock strength}

In the following, the three phases of post-construction settlement are compared with dam height for different rock strength categories. The adopted concept is the same as Hunter and Fell (2002); however, here, the time datum for the third phase is moved to the end of impoundment and different rates are considered for the relative crest settlements before and after impoundment. Additionally, the crest settlement attributed to first filling is considered to finish by the end of impoundment period. These changes yield more consistent results and facilitate the application of the prediction method.

\section{Crest settlement rate before beginning of impoundment vs. dam height}

Fig. 4 presents relative crest settlement rates after the end of construction and before start of impoundment versus corresponding dam heights. Despite the lack of data for dams of high strength rockfill, the graph shows an increase in the relative crest settlement rate with height. The effect of dam height on the relative crest settlement rates in this phase is associated with the fact that the rate of creep deformation of rockfill material is a function of stress level.

Extrapolating from the trendlines drawn in Fig. 4, the settlement rate is negligible for dams with heights of less than around $25 \mathrm{~m}$ to $40 \mathrm{~m}$ for high strength and very high strength rockfills, respectively. In other words, at stress levels smaller than certain values rockfill time-dependent deformations are not significant. This is consistent with the observations in laboratory oedometer and isotropic loading 
experiments on granular materials that indicate a threshold stress for stresses lower than which, creep strains are negligible (Marsal 1973; Clements 1981; Colliat-Dangus et al. 1988; Oldecop and Alonso 2007).

\section{Crest settlement attributed to impoundment vs. dam height}

In CFRDs, the deformations during the impoundment period are associated with an increase in stresses inside the dam body due to the reservoir load on the upstream surface. Simple finite element modelling (further explained in Fig. 12) shows that during impoundment of CFRDs, both mean and deviatoric stresses increase on the upstream side of the dam body. However, mean stress increases more significantly and consequently, the shear stress ratio decreases. Therefore, the settlement of the crest in this phase is considered to occur mostly due to increase in the mean stress.

In addition to the stress level increase, collapse due to wetting might also contribute to the settlements during impoundment. Wetting collapse occurs in rockfill structures due to the strength loss caused by increasing the amount of water in contact with rock particles. The rockfill moisture content might increase due to malfunctions of the concrete face, high downstream water level or penetration of water to downstream rockfill due to excessive precipitations. However, the effect of rockfill wetting collapse is not studied in details in this paper.

In this study, in order to obtain the deformations due only to stress increases caused by reservoir loading, the time-dependent component of settlements was subtracted from the total settlements during impoundment. To do so, the rate of time-dependent settlement during impoundment period $\left(2^{\text {nd }}\right.$ phase in Fig. 2.a) was assumed to be the same as that in the period before impoundment ( $1^{\text {st }}$ phase in Fig. 2.a); i.e., $\alpha_{1}$

The relative crest settlements attributed to impoundment values, $S_{\text {imp }}$, are plotted against dam height for the studied CFRDs in Fig. 5. It can be seen that the relative dam crest settlement due to impoundment 
generally increases with embankment height. The linear trend lines can be used as a guide for a predictive purpose.

The Toulnustouc main dam does not follow the general trend in Fig. 5. Although the relative settlement rates before impoundment (see Fig. 4) and those after impoundment (presented in next section, Fig. 7) are in the expected range, the relative crest settlement due to impoundment is much higher than other similar cases. This unusual behavior can be attributed to the fact that according to Fig. 6 , the impoundment of the dam took place mostly in February 2005, but the reservoir reached its maximum level during the snowmelt season, mid-April to mid-June 2005. Although the reservoir level increased much less during the snowmelt season comparing to the previous months $(20 \mathrm{~m}$ vs. $50 \mathrm{~m})$, the crest settled much more during this period. The reason might be that since the main rockfill zone of the dam was compacted without watering, the effects of snowmelt, along with the subsequent precipitations increased the wetting collapse in the downstream rockfill zones during the impoundment period.

\section{Crest settlement rates after impoundment vs. dam height}

Relative crest settlement rates after impoundment $\left(\alpha_{2}\right)$ are drawn versus the embankment heights in Fig. 7. For the dams of very high strength rockfill zones, the relative crest settlement rate increases slightly with dam height and is almost similar for all of the cases. The value is less than 0.05 for all of the studied dams. This means that for a $100 \mathrm{~m}$ high dam, the crest settlement attributed to time-dependent deformations after impoundment is less than $14 \mathrm{~cm}$ in 50 years of operation.

In the CFRDs constructed of high strength rockfill, there is a clear tendency of increasing relative longterm crest settlement rates with dam height. Although Fig. 7 generally correlates with the findings of Hunter and Fell (2002), when comparing the data with an adjusted time datum with the same data presented by Hunter and Fell (2002), more consistent values are obtainable for Kotmale and Winneke dams. Yet, for Winneke, the impoundment began 1.6 years after end of rockfill construction and took 3.8 years to end. Consequently, a large amount of time-dependent deformation had already taken place before 
and during the impoundment. Therefore, the rate of settlements relative to dam height is lower than expected for this dam. Additionally, since at the Mangrove Creek dam, the impoundment was still ongoing at the end of studied period, i.e. 15 years after end of construction, this dam does not yield any data point in this figure.

Similar to the data presented for post-construction settlements before impoundment, the dependence of relative settlement rates after impoundment on embankment heights tends to decrease with dam height. In other words, the evolution of relative settlement rates with dam height is nonlinear. It is also worth noting that, Shuibuya and Winscar dams fall off the general trend in this figure.

Despite the similarity of the general trend of relative settlement rate versus dam height curves before and after impoundment, the relative settlement rate values before impoundment are generally smaller comparing to those after impoundment. This aspect will be further examined in this paper.

\section{Post-construction crest settlement prediction method using rockfill modulus and rock strength}

The previously presented method has the following limitations:

- The embankment height does not perfectly represent the dam's geometry. Embankment slopes and valley shape are also influencing factors.

- Unconfined compressive strength of intact rock is not the only material parameter which affects the post-construction settlement of CFRDs. In order to reach a more reliable prediction method, a parameter shall be defined which also takes into account the shape and gradation of particles and the compaction method.

Therefore, a novel approach is introduced here, in which the post-construction settlements are determined using the dam's deformation behavior during construction. This method is adapted from the well-known concept that the secondary compression index $\mathrm{C}_{\alpha}$ and compression index $\mathrm{C}_{\mathrm{c}}$ are related for different types of earth materials. In other words, the time-dependent mechanical behavior of a material in constant stress 
can be estimated through its behavior during loading. The material can be a fine-grained soil (Mesri and Godlewski 1977), sand (Mesri and Vardhanabhuti 2009) or rockfill (Oldecop and Alonso 2007; Cormier and Konrad 2015). In the case of rockfill dams, secondary compression index corresponds to postconstruction settlement behavior and compression index corresponds to the rockfill construction period.

In this study, the secant modulus of the main rockfill zone at the end of construction (equation (1) and Fig. 8) is used to illustrate the behavior during construction. The rockfill secant modulus, for a certain rockfill layer, at end of construction can be defined by dividing the calculated vertical stresses by the strains inferred from readings of settlement gauges:

$$
E_{R C}=\frac{\sigma_{z}}{\delta_{s} / d_{1}}
$$

where, as shown in Fig. 8, $d_{1}$ is thickness of the considered layer, $\gamma$ is the unit weight of the above fill layers, and, $\delta_{s}$ is the vertical displacement of the considered layer. In order to calculate the moduli, the stress at the mid-height of the layer $\sigma_{z}$ is considered in this paper and is calculated using a simple linear elastic numerical analysis. In this way, the effect of embankment shape on vertical stress is taken into account. Other than Shuibuya, Tianshengqiao and Winscar dams for which the moduli are calculated by the authors, in this section, the values of modulus during construction, $\mathrm{E}_{\mathrm{RC}}$, are taken from Hunter and Fell (2002). These values are calculated for the lower half to one third of the dam height. Note that, this modulus calculation method differs from that of Fitzpatrick et al. (1985), Pinto and Marques Filho (1998), and Giudici et al. (2000), in the sense that first, here, the shape of embankment is considered; i.e. the vertical stress is not simply taken as the multiplication of fill height to fill density. Secondly, in order to determine the modulus, the vertical stress is calculated in this paper for the mid-height, instead of the top, of layer. The calculated stress at mid-height is supposed to yield the average vertical stress of layer. An example of modulus calculation is presented later in this paper. 


\section{Crest settlement rate before beginning of impoundment vs. rockfill secant modulus}

The relative crest settlement rates before impoundment are shown versus rockfill secant modulus at end of construction in Fig. 9. For the dams where the main rockfill zone is constructed of very high strength rockfill, there is a slight decrease in the relative crest settlement rate, $\alpha_{1}$, with secant modulus at the end of construction. For the dams where the main rockfill zone is constructed of high strength rockfill, the relative crest settlement rate decreases more clearly with rockfill secant modulus. In other words, the stiffer the rockfill layers are during construction, the less settlement they undergo in the post-construction period. A power law curve is fitted to the curve in order to allow its use for predictive purposes.

The Mackintosh dam, which was considered as an outlier in Fig. 4 falls inside the generally expected trend in Fig. 9. This shows the reliability of this predictive approach. Since the in-situ behavior of the same structure is being used for prediction, it reduces the shortcomings of the other prediction approaches.

\section{Crest settlement attributed to impoundment vs. rockfill secant modulus}

The concept of linking the load-deformation behavior of the dam during construction to its behavior afterwards is also used here. Fig. 10 presents the relative crest settlement attributed to impoundment versus average rockfill secant modulus at end of construction for different CFRDs. Once again, the higher the secant modulus of the rockfill at the end of construction, the lower the dam's relative settlement attributed to impoundment. However, the effect of intact rock strength is not significant here. Except for one case, CFRDs constructed of both very high and high strength rockfill zones lie along the same general trend line. In other words, by comparing the settlements caused by impoundment with rockfill secant modulus, the effect of rock intact strength decreases. Note that, since in the case of CFRDs deformations during both construction and impoundment represent stress-strain behavior of their materials due to gradual increases in stress level, the existence of a relationship between the two phases is quite rational. 


\section{Crest settlement rate after impoundment vs. rockfill secant modulus}

Fig. 11 shows the long-term relative crest settlement versus rockfill secant modulus for the studied CFRDs. The same trend as settlement rates before impoundment (Fig. 9) is observed here. The only difference is that, after impoundment, the relative settlement rates are generally higher than those in Fig. 9 and the difference between the trend lines, for the two strength categories, is more evident.

It is interesting to note that despite very high strength of rockfill in Foz Do Areia and Reece dams, the rockfill has low secant modulus at the end of construction, even less than some of the high strength rockfills. Additionally, as can be seen in Table 2, rockfill void ratio is high for the two cases. Therefore, it can be inferred that the void ratio affects the rockfill stress-strain behavior during construction more than the intact strength of rock particles. But, for the time-dependent deformations, the intact strength is more influential.

Winscar and Shuibuya dams, which were outside the trends observed in the graphs of $\alpha_{2}$ versus dam height, fall well inside the trend in Fig. 11. This shows the efficiency of the current method. It is also worth noting that the Winneke dam, which was outside the trend observed for the long-term relative crest settlement (after impoundment) of dams constructed of high strength rockfill, is well inside the expected trend in the other two sections (time-dependent settlements before impoundment and settlements attributed to impoundment). This validates the hypothesis that its unexpected behavior during the longterm settlement phase is due to the delay in completion of impoundment.

A summary of the parameters calculated for the studied cases and used in the previous three sections is presented in Table 3.

\section{Comparison between time-dependent deformations before and after impoundment}

In this section, the relative crest settlement rates before and after impoundment are compared to study the effect of changes in stress distribution and properties of materials on time-dependent deformation of 
CFRDs. In order to compare the stress state inside an embankment before and after impoundment, a generic $100 \mathrm{~m}$ high embankment having slopes of 1 vertical to 1.4 horizontal was modeled using the Plaxis 2D Hardening soil model. This model, which uses theory of plasticity to reproduce hyperbolic axial strain-deviatoric stress in a drained triaxial test, and, includes soil dilatancy, is quite common in modeling rockfill embankments. The mechanical parameters used for the model are presented in Table 4. In the table, $E_{50}^{\text {ref }}$ and $E_{u r}^{\text {ref }}$ are the secant modulus in $50 \%$ of maximum shear stress and unloading/reloading stiffness in a standard triaxial test, respectively; $E_{\text {oed }}^{r e f}$ is the tangent stiffness for primary oedometer loading at a reference stress, $p^{\text {ref }}$; and $\mathrm{m}$ is the power for stress level dependency of the stiffness moduli:

$$
E \approx E^{r e f}\left(\sigma / p^{r e f}\right)^{m}
$$

where $\sigma$ is "minimum principal stress" for $E_{50}^{r e f}$ and $E_{u r}^{r e f}$ and "minimum principal stress over $K_{0}^{n c "}$ for $E_{\text {oed }}^{r e f} . K_{0}^{n c}$ is the $K_{0}$ value for normal consolidation, $\vartheta_{u r}$ is the Poisson's ratio for unloading/reloading and $R_{f}$ is the failure ratio (ultimate over asymptotic deviatoric stress). C, $\varphi$, and $\psi$ are cohesion, friction angle, and dilation angle respectively.

The construction of the generic embankment was modeled using the software's staged construction option in which $10 \mathrm{~m}$ lifts were considered. After construction modelling, the reservoir load was applied on the impervious upstream face in a single stage. The computed mean effective stress, deviatoric stress and relative shear stress $\left(\tau_{\operatorname{mob}} / \tau_{\max }\right)$, before and after application of reservoir load are shown in Fig. 12. $\tau_{\operatorname{mob}}$ is the mobilized shear strength or the radius of the Mohr circle and $\tau_{\max }$ is the maximum value of the shear stress, for the case when the Mohr circle expands and touches the coulomb failure envelope considering a fixed center. Therefore, $\tau_{\operatorname{mob}} / \tau_{\max }$ is an indicator of the proximity of an element to the failure envelope and varies between 0 for isotropic stress state to 1 for failure state. As can be seen, by applying reservoir load, both mean and deviatoric stresses increase on the upstream side and centerline of the embankment. However, the mean stress increases more significantly and the relative shear stress, decreases in the 
upstream side of the embankment. While stresses generally increase inside the embankment, if considering a Coulomb failure criterion, the material moves away from failure state due to the induced stresses. This is an advantage of CFRDs compared to other types of embankment dams, where impoundment increases the risk of slope instability. Additionally, it can be implied that the instantaneous, as well as long-term deformations, caused by impoundment in a CFRD is mostly due to increase in confining pressure rather than shear stress.

Returning to the data from studied CFRDs, Fig. 13 shows how the settlement rates before and after impoundment compare for different cases. Despite some exceptions, the relative settlement rates become larger after impoundment. Generally, the $\alpha_{2} / \alpha_{1}$ ratio lies between 0.8 and 2.5 . The relative crest settlement rate after impoundment, $\alpha_{2}$ is very small for Winneke dam because it has undergone a very long settlement period before the end of impoundment (5.4 years). Neglecting this case, generally, the dams constructed of high strength rockfill zones show higher $\alpha_{2} / \alpha_{1}$ values in comparison with those constructed of very high strength rockfill. It can be inferred that for the rockfill of lower strength, the strain rate is more influenced by the stress level than the rockfill of higher strength. This is in accordance with the results of the previous sections where the relative crest settlement rates of dams constructed of very high strength rockfill zones show less dependency on the dam height.

Reservoir impoundment has two influences on the behavior of CFRDs: first, as discussed previously, the stress distribution inside the dam changes due to the load application on the upstream face; second, the rockfill material undergoes changes, some of the cracks inside the particles propagate, and particles break and fill the voids. Additionally, some of the asperities of the particles break. The change in properties throughout the time, and normally stiffening of the material, is called the aging effect. The first aspect results in larger time-dependent deformations while the second generally leads to smaller deformations. As can be seen in Fig. 13, in most of the studied cases, the first mechanism is prevailing (right side of $\alpha_{2}=\alpha_{1}$ line) and in some, the second one is dominant (left side of $\alpha_{2}=\alpha_{1}$ line). 
In order to study the ageing effect, the ratios of relative crest settlement rates, after and before impoundment, $\alpha_{2} / \alpha_{1}$, are drawn versus the elapsed time between end of construction and end of impoundment (start of the third phase) (Fig. 14). A clear trend can be seen in this figure for the dams constructed of high strength rockfill. As the time interval increases, the ratios of settlement rates decrease. In other words, the longer the time before start of the third phase (the end of impoundment), the more significant the effect of aging and the less the dam's crest settlement in the period afterwards. The Winneke dam, which was considered an outlier in Fig. 13, falls very well inside the trend in Fig. 14. For the dams constructed of very high strength rockfill on the other hand, no clear trend is observed. This may indicate that the aging effect is more influential in the less stiff rockfill, where the particles break more frequently and the voids fill more often between the rock particles. Therefore, the number of inter-particle contact points increases and less breakage takes place in the subsequent phase.

\section{Example of post-construction crest settlement prediction}

The La Yesca dam in Mexico, a 208m high and 628m long structure, was chosen to permit an actual prediction of the post-construction settlement of a CFRD. This can be considered as a "class B" prediction according to (Lambe 1973) since the results are not known at the time prediction is made. Construction of the dam body began in 2008 and ended in April 2012. As can be implied from the existing data, the impoundment started right after end of construction and ended in September 2013. However, no data on post-construction settlements of the dam was found. The material properties and deformation of the dam during construction are presented in Marengo-Mogollón and Rivera-Constantino (2012). The typical cross section of the dam includes three major zones (Fig. 15). The main embankment zones (3A \& 3B) are comprised of rockfill and coarse-grained alluvial soil. Therefore, the La Yesca dam is different from the studied cases in this respect. Despite the lack of detailed data, the UCS of the rockfill (that is originated from ignimbrites) is assumed to be in the very high strength category.

a) Using dam height and rockfill strength: The height of the maximum section of the dam is $195 \mathrm{~m}$ at 
the centerline from the crest to the foundation. Therefore, using Fig. 4, relative crest settlement rate after construction, $\alpha_{1}$ extrapolates $0.055 \%$ per $\log$ cycle of time. Although the impoundment of the dam started right after end of construction and the first phase does not exist in this case, $\alpha_{1}$ must be used to calculate the time-dependent deformations during impoundment. So, considering that impoundment finishes one year and four months (1.33 years) after end of construction, settlement of

$$
S(\% \text { dam height })=0.055 \times \log (1.33 / 0.1)=0.06 \% \text { or } 12 \mathrm{~cm}
$$

must be summed with the settlements attributed to first filling to estimate total settlement during impoundment period. The crest settlement attributed to stress increase caused by impoundment can be calculated extrapolating from Fig. 5. Considering the x value (dam height $=195 \mathrm{~m})$, the $S_{i m p}$ amount is estimated as $0.05 \%$ of dam height, or $10 \mathrm{~cm}$. Likewise, extrapolating from Fig. 7 (x value = dam height $=195 \mathrm{~m})$, the relative crest settlement rate after impoundment is estimated as $0.05 \%$ per log cycle of time. Therefore, for instance, in 50 years of operation after impoundment, the relative crest settlement would be $0.052 \times \log (50 / 0.1)=0.14 \%$ dam height or $27.5 \mathrm{~cm}$. Note that the beginning of the time interval for estimation of settlements in each phase, $t_{1}$, is considered to be 0.1 years in the calculations (e.g. in equation (3)) since it yields acceptable results for the studied cases. Considering smaller values of beginning of the time interval tends to overestimate the settlements.

b) Using rockfill secant modulus and strength: The vertical deformation contours of La Yesca dam measured with hydraulic levels at end of construction are shown in Fig. 16. As it is indicated, for a layer located in the bottom one third of the dam, the vertical settlement, $\delta_{S}$, is approximately $80 \mathrm{~cm}$ and the layer thickness, $d_{1}$, equals $65 \mathrm{~m}$. The vertical stress contours relative to dam height, computed from linear elastic analysis of a generic homogeneous, symmetrical embankment with the same embankment slopes as La Yesca dam, are presented in Fig. 17. Using this figure, the vertical stress at the mid-height of the considered layer (supposedly, the average vertical stress of the layer) can be calculated as: 


$$
\frac{\sigma_{z}}{\gamma H}=0.68 \Rightarrow \sigma_{z}=0.68 \times 20.1 \times 195=2,665 \mathrm{kN} / \mathrm{m}^{2}
$$

Thus, the modulus will be:

$$
E_{R C}=\frac{\sigma_{z}}{\left(\delta_{s} / d_{1}\right)}=\frac{2861}{(0.8 / 65)}=216,550 \mathrm{kN} / \mathrm{m}^{2}
$$

Conducting the same procedure for two other layers adjacent to the foundation with different thicknesses, an average modulus of $210 \mathrm{MPa}$ was calculated for prediction.

Now, using the calculated rockfill secant modulus, extrapolating from Fig. 9, $\alpha_{1}$, equals $0.02 \%$ per $\log$ cycle of time (time-dependent settlement during impoundment period would equal $0.02 \%$ of dam height using the same method as in equation (3). Likewise, implementing Fig. 10, the crest settlement attributed to first filling equals $0.02 \%$ of dam height, i.e. $4 \mathrm{~cm}$. Also, using Fig. 11, the relative crest settlement rate after impoundment, $\alpha_{2}$, equals $0.025 \%$ per $\log$ cycle of time i.e. $0.07 \%$ (or $13.5 \mathrm{~cm}$ ) in 50 years after impoundment. The relative settlements calculated using this method are shown in Fig. 18 for the periods before and after impoundment.

Table 5, presents a summary of estimated parameters for post-construction settlements of La Yesca dam. The second method yields smaller settlement parameters compared to the first method. The settlements of La Yesca dam during construction were small compared to similar dams. This yields very large modulus for rockfill and consequently, small values for post-construction settlement. It is expected that the values from the modulus method yield more reliable estimations. It must be noted that as the annual rainfall histogram of the dam indicates, the impoundment period of the dam includes two rainy seasons with maximum monthly precipitation of $300 \mathrm{~mm}$. Therefore, it can be anticipated that the settlements during impoundment be higher than the estimated values due to wetting collapse, especially if the rockfill had not been sluiced during construction. 


\section{Limitations of the presented methods}

In this study, the unconfined compressive strength of intact rock was used to characterize the rock quality. However, the susceptibility of the rock to lose its strength while in contact with water, which leads to collapse due to wetting in rockfill, must also be considered. This aspect is of essential importance in areas with high precipitation and where rockfill is not watered during construction. The Roadford asphaltic concrete face rockfill (sandstone and mudstone) dam (Charles 2008) and the Martin Gonzalo concrete face rockfill (slate and greywacke) dam (Justo and Durand 2000) are two examples of impervious upstream face dams where significant wetting collapse settlement has taken place. Compared to the other cases evaluated in this study, the moduli at end of construction values are very low for Roadford and Martin Gonzalo (32MPa and 16MPa respectively). Therefore, low rockfill secant modulus at end of construction can be also an indicator of susceptibility to wetting collapse. This aspect needs further investigation.

It must also be noted that the presented method is a phenomenological approach. While all of the estimations and calculations in this study depend on the definition of the time datum, according to Leroueil (2001), any change in the time frame datum must not change results of the response of a system due to the axiom of objectivity. Nevertheless, the guidelines presented here, yield a representative engineering estimation of the post-construction behavior of the CFRDs.

\section{Conclusions}

In the presented study, the post-construction crest settlement of CFRDs is linked to the in-situ mechanical properties of rockfill during construction and the geometry of the embankment through an empirical method. The presented methods can be used to overcome some limitations of numerical models and laboratory experiments such as scale effects, difference between densities and moisture contents in the field and in laboratory, diversity of materials in a rockfill embankment and complexity of stress paths in the field. Additionally, after assessment of the time-dependent settlements of the studied cases, ageing is 
shown to significantly influence the settlement rates for compacted rockfill within the high strength category.

\section{Acknowledgement}

The authors gratefully acknowledge the financial support of the Natural Sciences and Engineering Research Council of Canada (NSERC) - Hydro-Québec Industrial Research Chair for life cycle optimization of embankment dams. The authors also extend their appreciation to their industrial partners: Hydro-Québec, SNC-Lavalin, Qualitas, WSP, Golder Associates, Klohn Crippen Berger, ConeTec, and Hatch. 


\section{References}

Alonso, E.E., Pinyol, N.M., and Olivella, S. 2005. A review of Beliche Dam. Géotechnique, 55(4), pp.267-285.

Alonso, E.E., Tapias, M., and Gili, J. 2012. Scale effects in rockfill behaviour. Géotechnique Letters, 2(79), pp.155-160.

Charles, J.A. 2008. The engineering behaviour of fill materials : the use, misuse and disuse of case histories. Geotechnique, 58(7), pp.541-570.

Clements, R.P. 1984. Post-construction deformation of rockfill dams. ASCE Journal of Geotechnical Engineering, 110(7), pp.821-840.

Clements, R.P. 1981. The deformation of rockfill; inter-particle behaviour, bulk properties and bebaviour in dams. King's College, London.

Colliat-Dangus, J.L., Desrues, J., and Foray, P. 1988. Triaxial Testing of Granular Soil Under Elevated Cell Pressure. Advanced Triaxial Testing of Soil and Rock, ASTM STP 977, pp.290-310.

Cooke, J.B. 1984. Progress in Rockfill Dams. Journal of Geotechnical Engineering (ASCE), 110(10), pp.1381-1414.

Cormier, V., and Konrad, J.-M. 2015. Short and long term compressibility of rock particle assemblages. In Proceedings of the 68th Canadian Geotechnical Conference; GéoQuébec; Sept. 20-23. Quebec.

Fitzpatrick, M.D., Cole, B., Kinstler, F., and Knoop, B. 1985. Design of concrete-faced rockfill dams. In Proceedings of the Symposium on Concrete Face Rockfill Dams - Design, Construction and Performance, (Cooke and Sherard ed.) Detroit, Michigan, ASCE New York. pp. 410-434.

Giudici, S., Herweynen, R., and Quinlan, P. 2000. HEC experience in concrete faced rockfill dams - past, present and future. In Proceedings of the International Symposium on Concrete Faced Rockfill Dams. Beijing, pp. 29-46.

Hunter, G. and Fell, R. 2002. The Deformation Behaviour of Rockfill. The University Of New South 
Wales, School Of Civil And Environmental Engineering, Uniciv Report No. R-405, (January).

ICOLD 2010. Concrete face rockfill dams; concepts for design and construction. Bulletin 141.

Justo, J.L., and Durand, P. 2000. Settlement-time behaviour of granular embankments. International Journal for Numerical and Analytical Methods in Geomechanics, 24(3), pp.281-303.

Kermani, M. 2016. Prediction of post-construction settlements of rockfill dams, based on construction field data. $\mathrm{PhD}$ thesis, Université Laval.

Lambe, T.W. 1973. Predictions in soil engineering. Géotechnique, 23(2), pp.151-202.

Marachi, N.D., Chan, C.K., Seed, H.B., and Duncan, J.M. 1969. Strength and deformation characteristics of rockfill materials, University of California, Berkeley; Report No. TE-69-5.

Marengo-Mogollón, H., and Rivera-Constantino, R. 2012. Geotechnical design for " La Yesca " dam : description of its behavior during the construction stage and first filling. In CDA Annual Conference, September 22 -27, 2012. Saskatoon, SK, Canada.

Marsal, R.J. 1973. Mechanical properties of rockfill. Embankment Dam Engineering, (Casagrande Volume. Hirschfeld, RC and Poulos, SJ, ), pp.109-200.

Marulanda, A. 2013. Recent successful very high CFRD's. In Annual Canadian Dam Associatin (CDA) Conference. Montreal, Canada.

Mesri, G. and Godlewski, P.M. 1977. Time- and stress-compressibility interrelationship. ASCE, Journal of the geotechnical engineering division, 103(GT5), pp.417-430.

Mesri, G. and Vardhanabhuti, B. 2009. Compression of granular materials. Canadian Geotechnical Journal, 46(4), pp.369-392.

Milligan, V. and Coyne, L. 2005. Review of factors influencing the settlement of rockfill dams. In K.Y. Lo Symposium, The University of Western Ontario. pp. 1-31.

Oldecop, L.A. and Alonso, E.E. 2007. Theoretical investigation of the time-dependent behaviour of 
rockfill. Géotechnique, 57(3), pp.289-301.

Parkin, A.K. 1977. The Compression of Rockfill. Australian Geomechanics journal, pp.33-39.

Pinto, N.D.. and Marques Filho, P.L. 1998. Estimating the maximum face deflection in CFRDs. International Journal on Hydropower and Dams, 5, pp.28-32.

Ramon, A., Alonso, E.E., and Romero, E.E. 2008. Grain size effects on rockfill constitutive behavior. In: Unsaturated Soils. Advances in Geo-Engineering: Proceedings of the 1st European Conference on Unsaturated Soils, Durham (U.K.), (2001), pp.341-347. Available at: ISBN 978-0-415-47692-8.

Sowers, G.F., Williams, R.C., and Wallace, T.S. 1965. Compressibility of Broken Rock and the Settlement of Rockfills. In Proceedings of 6th ICSMFE; vol. 2. Montreal, pp. 561-565.

Soydemir, C., and Kjaernsli, B. 1979. Deformations of membrane-faced rockfill dams. In 7th European Conference on Soil Mechanics and Foundation Engineering. Brighton, England, pp. 281-284. 


\section{Figure captions}

Fig. 1. Post construction crest settlement of Bastyan dam (adapted from Hunter and Fell 2002)

Fig. 2. Post construction crest settlement of Bastyan dam a) time datum at the end of main rockfill construction; b) time datum at the end of impoundment (data from Hunter and Fell 2002)

Fig. 3. Typical zoning of concrete face rockfill dams (adapted from ICOLD 2010)

Fig. 4. Relative crest settlement rate before impoundment vs. dam height

Fig. 5. Crest settlement per dam height attributed to impoundment vs. dam height for studied CFRDs

Fig. 6. Evolution of crest settlement per dam height and reservoir water level history of Toulnustouc main dam in the highest section

Fig. 7. Relative crest settlement rate after impoundment vs. dam height

Fig. 8. Calculation of modulus during construction (adapted from Hunter and Fell 2002).

Fig. 9. Relative crest settlement rate before impoundment vs. rockfill secant modulus at end of construction

Fig. 10. Relative crest settlement attributed to impoundment vs. rockfill secant modulus at end of construction

Fig. 11. Relative crest settlement rate after impoundment vs. rockfill secant modulus at the end of construction

Fig. 12. Stress state inside a generic CFRD a) before, b) after impoundment

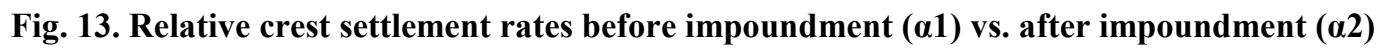

Fig. 14. The ratio of relative crest settlement rates after and before impoundment vs. time elapsed from the end of rockfill construction (EoC) to the end of impoundment (EoI)

Fig. 15. Typical cross section of La Yesca dam(adapted from Marengo-Mogollón and Rivera-Constantino 2012)

Fig. 16. Contours of settlements (cm) at La Yesca Dam for the end of construction (modified from Marengomogollón and Rivera-Constantino 2012)

Fig. 17. Contours of vertical stress for a generic embankment with 1 horizontal to 1.4 vertical slope at end of construction $(\mathrm{H}=$ dam height in the section, and $\gamma=$ fill density) 
Fig. 18. Post-construction crest settlement prediction of La Yesca dam a) before and b) after the end of impoundment 


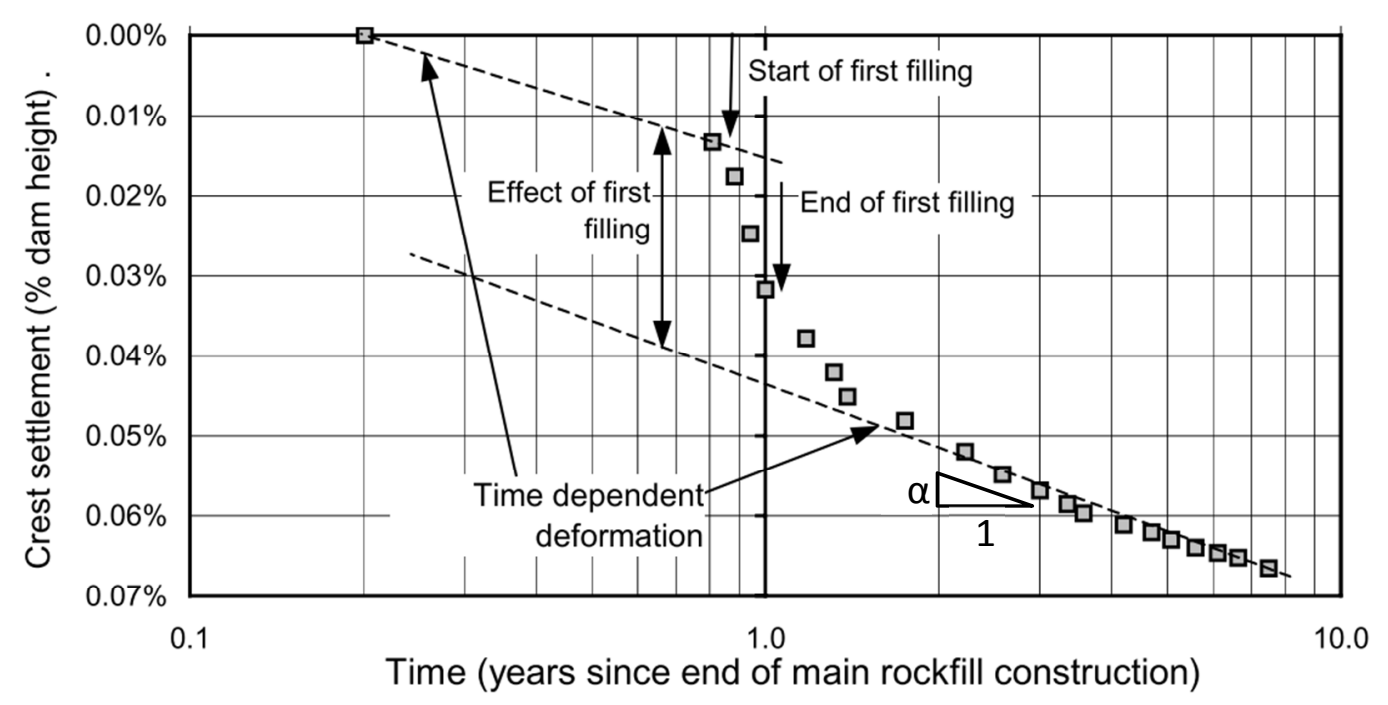

Fig. 1. Post construction crest settlement of Bastyan dam (adapted from Hunter \& Fell, 2002) 


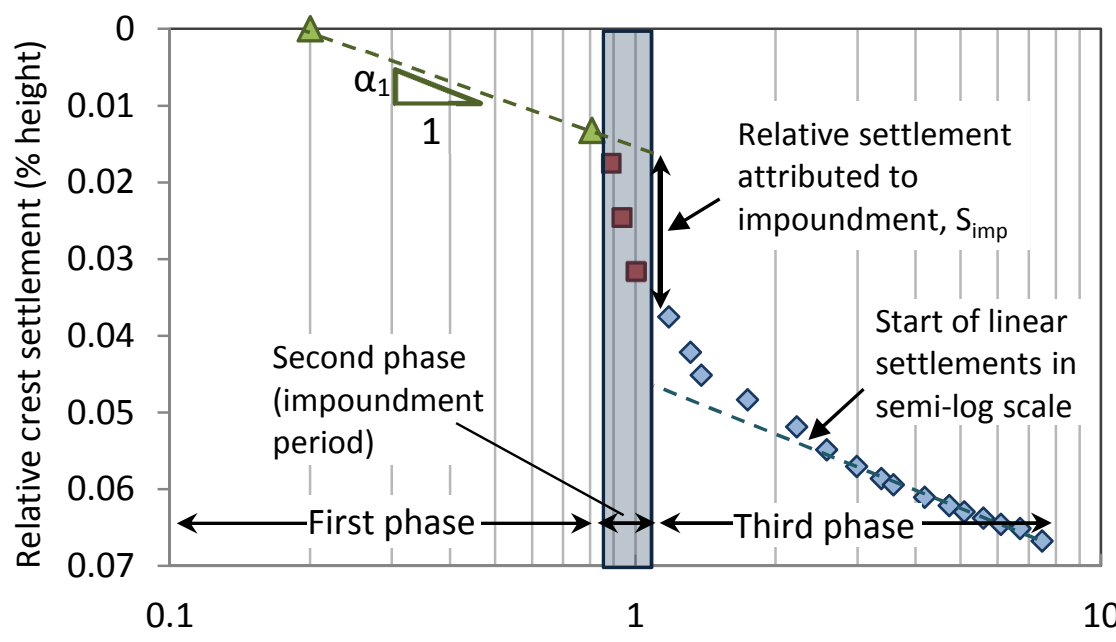

Time (years since end of main rockfill construction)

(a)

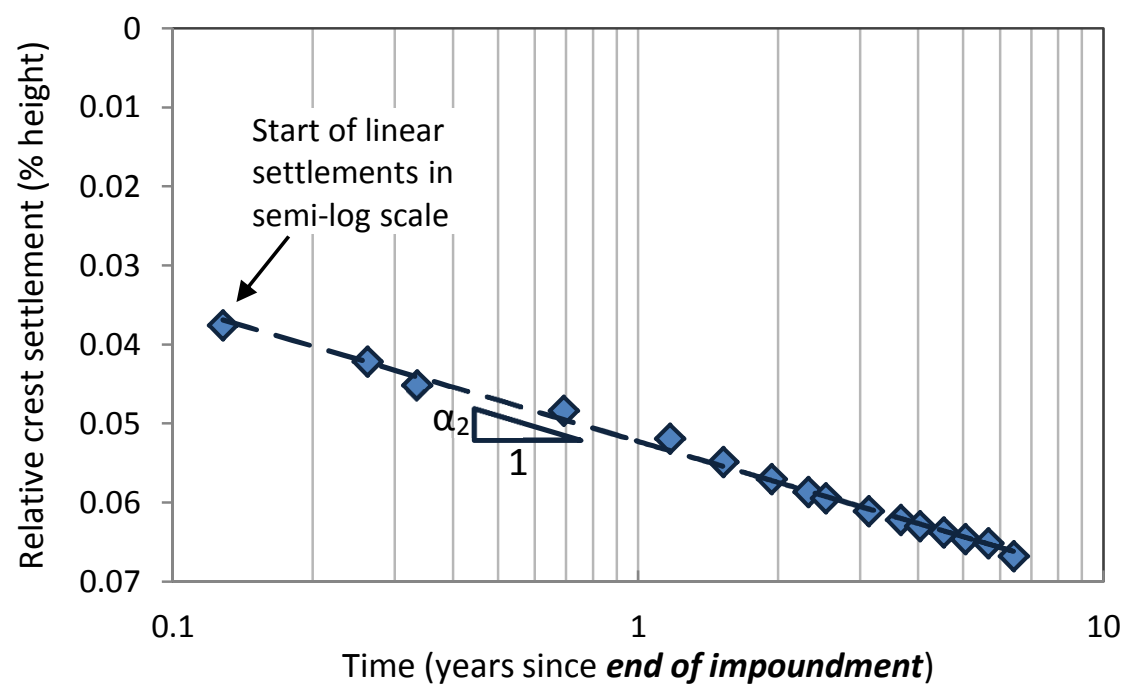

(b)

Fig. 2. Post construction crest settlement of Bastyan dam a) time datum at the end of main rockfill construction; b) time datum at the end of impoundment (data from Hunter and Fell, 2002) 


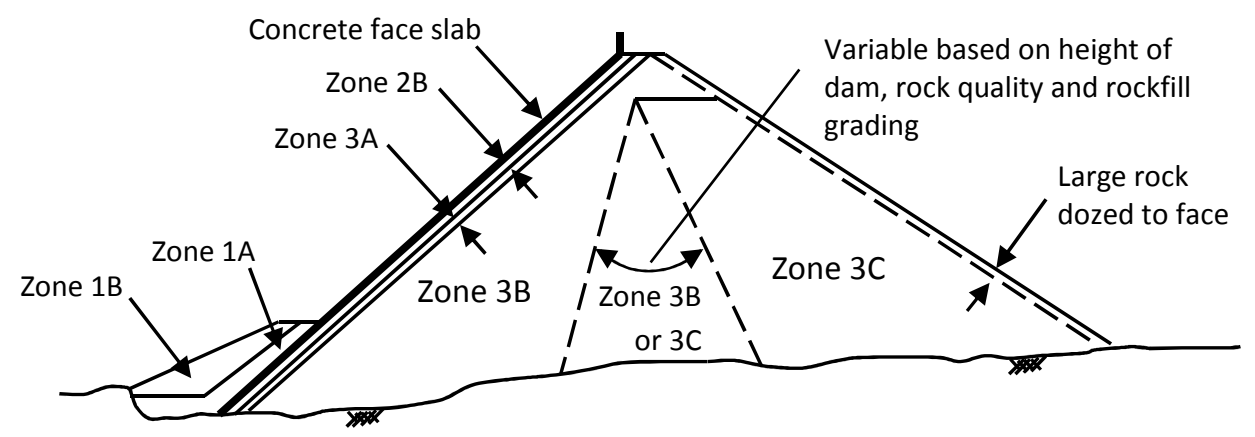

Fig. 3. Typical zoning of concrete face rockfill dams (adapted from ICOLD 2010)

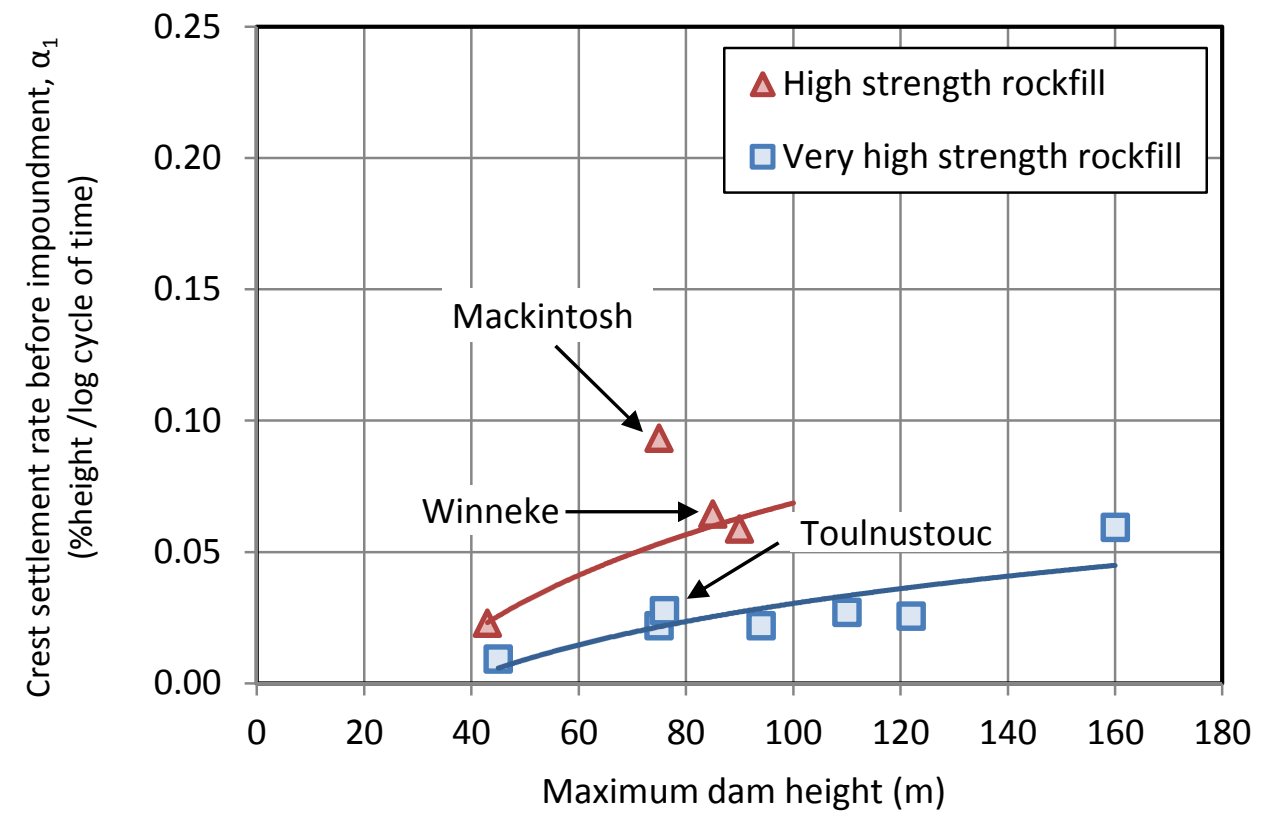

Fig. 4. Relative crest settlement rate before impoundment vs. dam height 


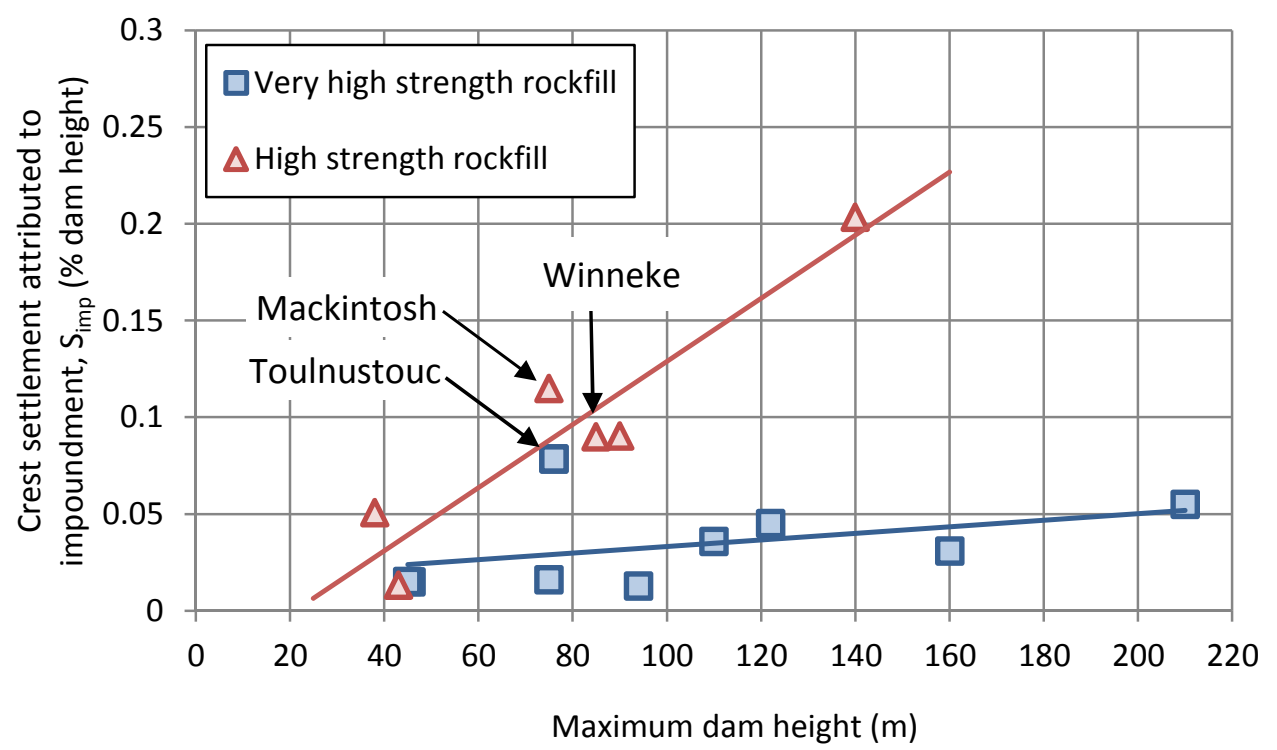

Fig. 5. Crest settlement per dam height attributed to impoundment vs. dam height for studied CFRDs

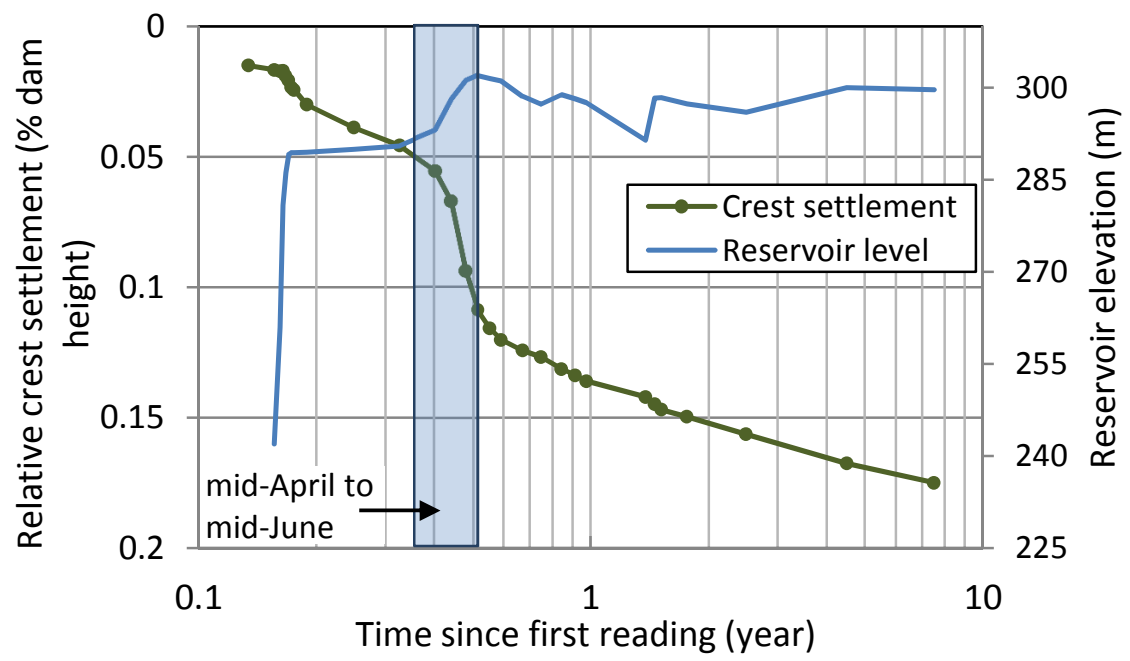

Fig. 6. Evolution of crest settlement per dam height and reservoir water level history of Toulnustouc main dam in the highest section 


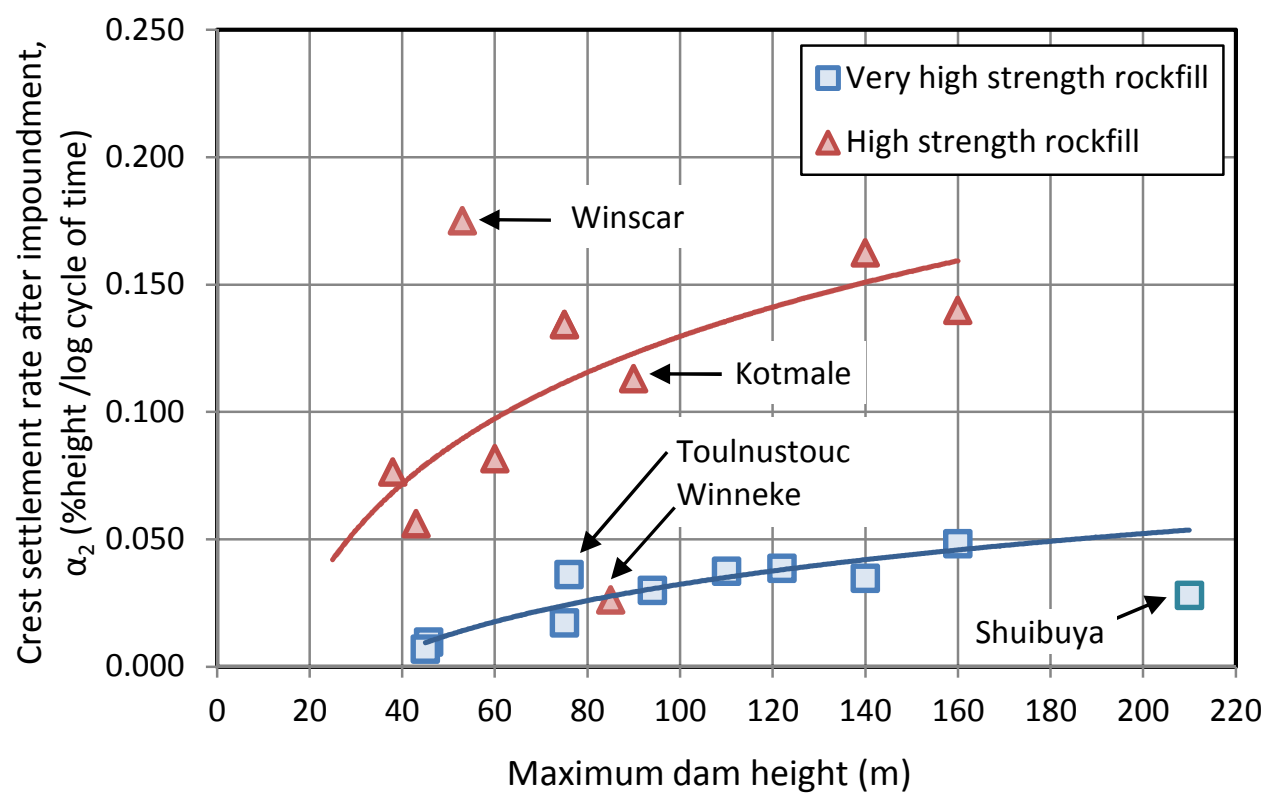

Fig. 7. Relative crest settlement rate after impoundment vs. dam height

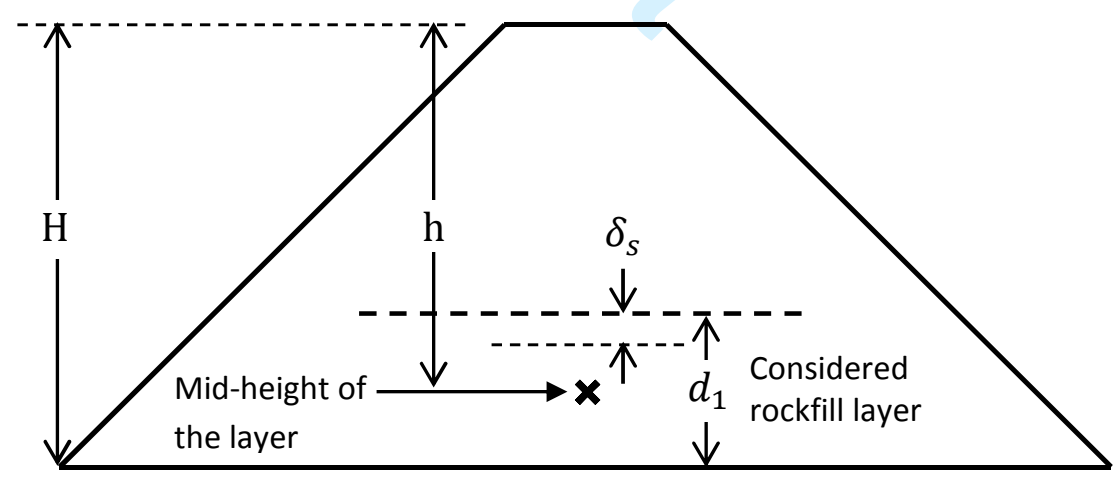

Fig. 8. Calculation of modulus during construction (adapted from Hunter \& Fell 2002). 


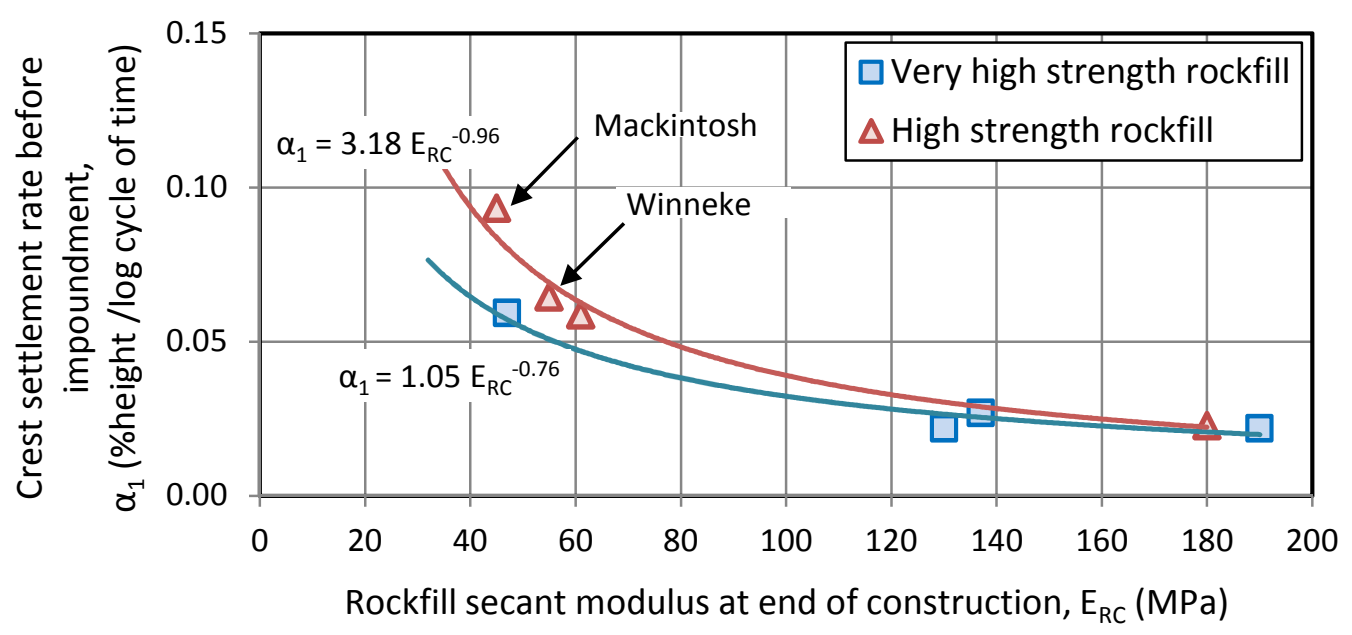

Fig. 9. Relative crest settlement rate before impoundment vs. rockfill secant modulus at end of construction

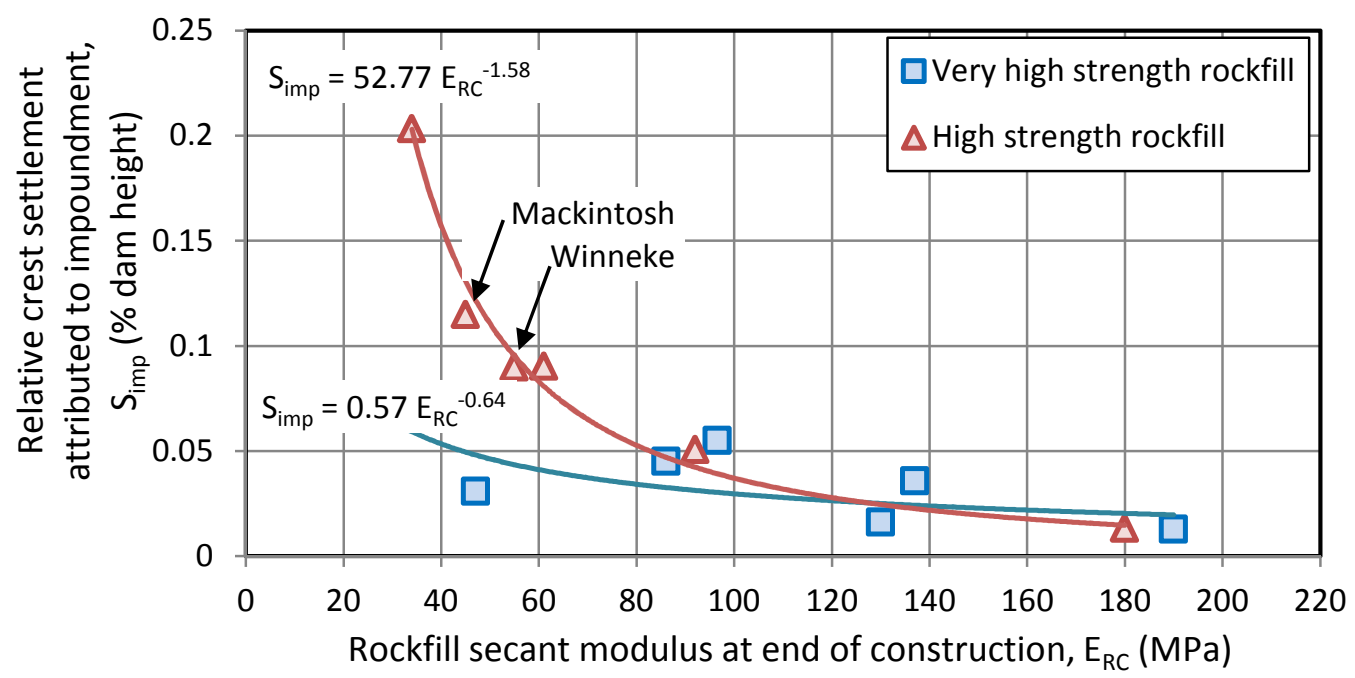

Fig. 10. Relative crest settlement attributed to impoundment vs. rockfill secant modulus at end of construction 


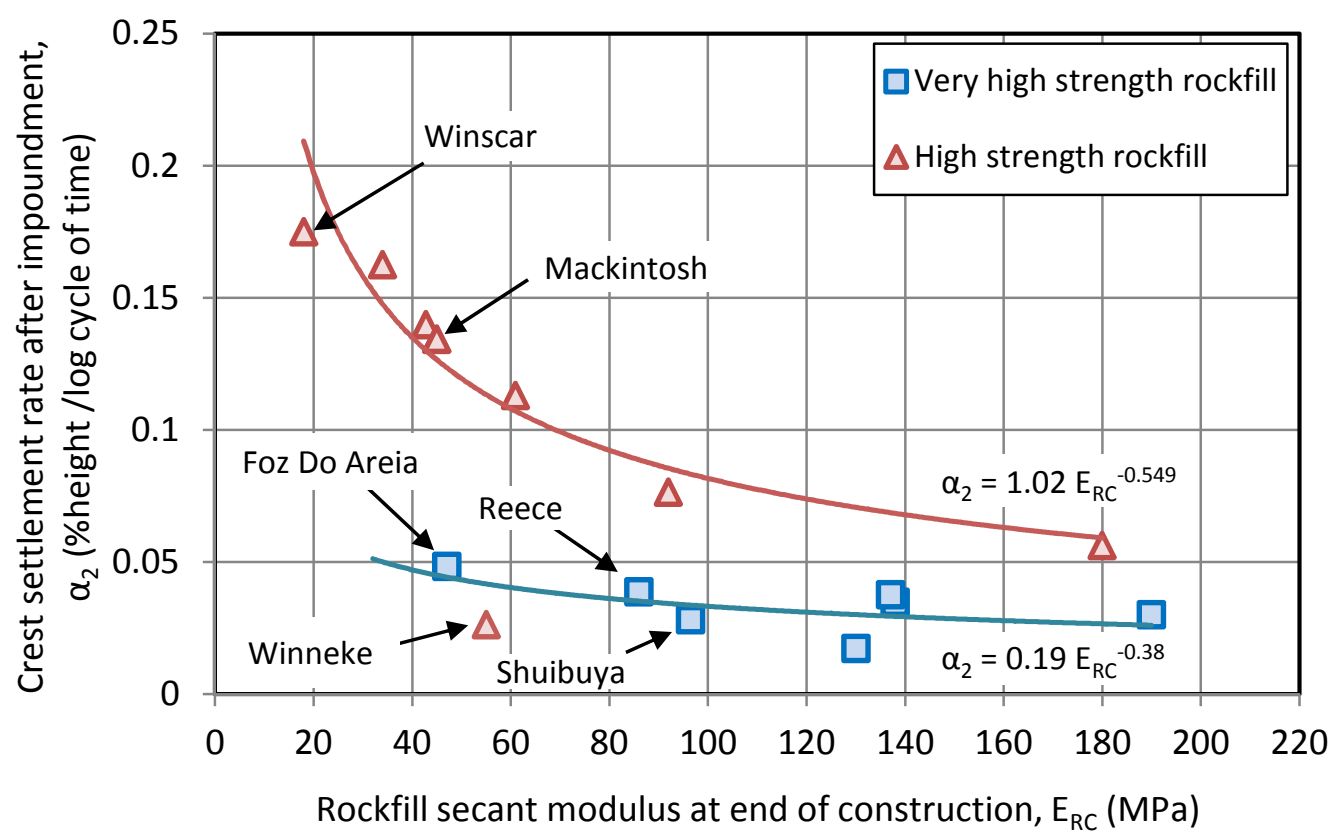

Fig. 11. Relative crest settlement rate after impoundment vs. rockfill secant modulus at the end of construction 


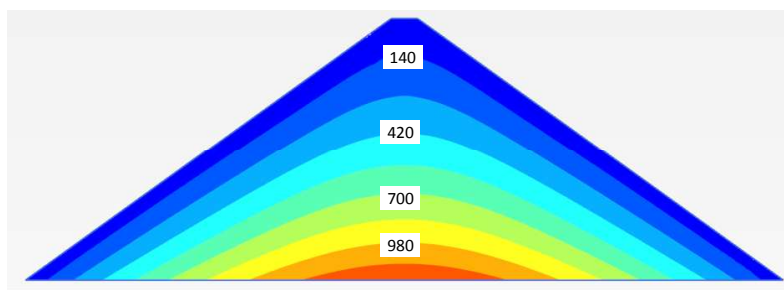

Mean effective stress $\mathrm{p}^{\prime}(\mathrm{kPa})$

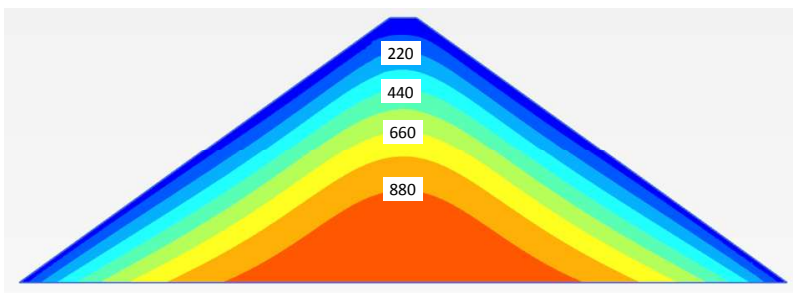

Deviatoric stress q $(\mathrm{kPa})$

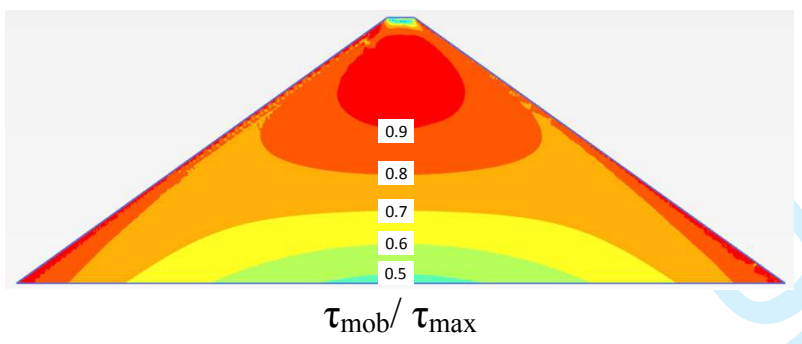

(a)

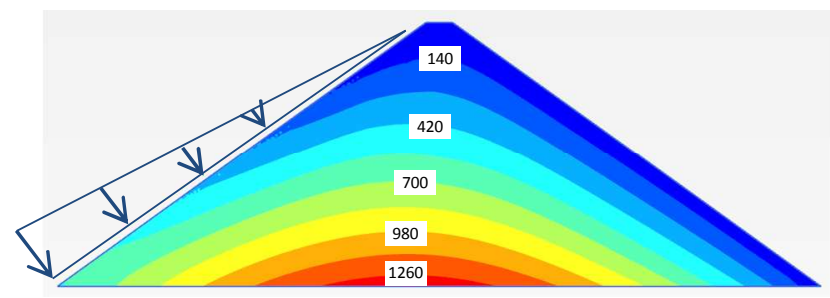

Mean effective stress $\mathrm{p}^{\prime}(\mathrm{kPa})$

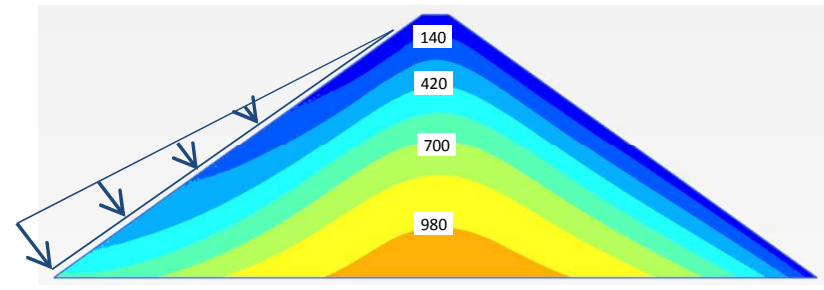

Deviatoric stress q $(\mathrm{kPa})$

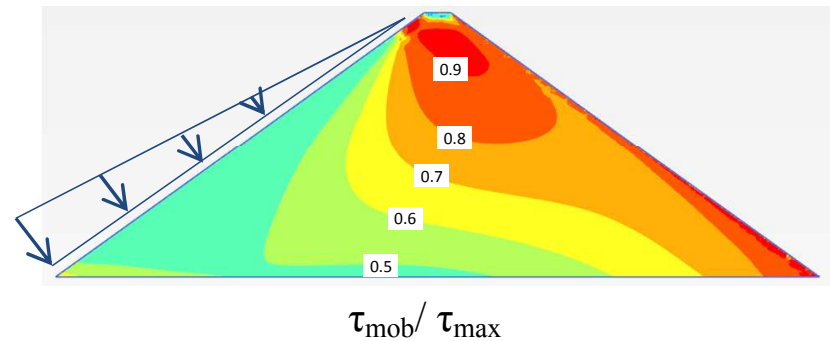

(b)

Fig. 12. Stress state inside a generic CFRD a) before, b) after impoundment

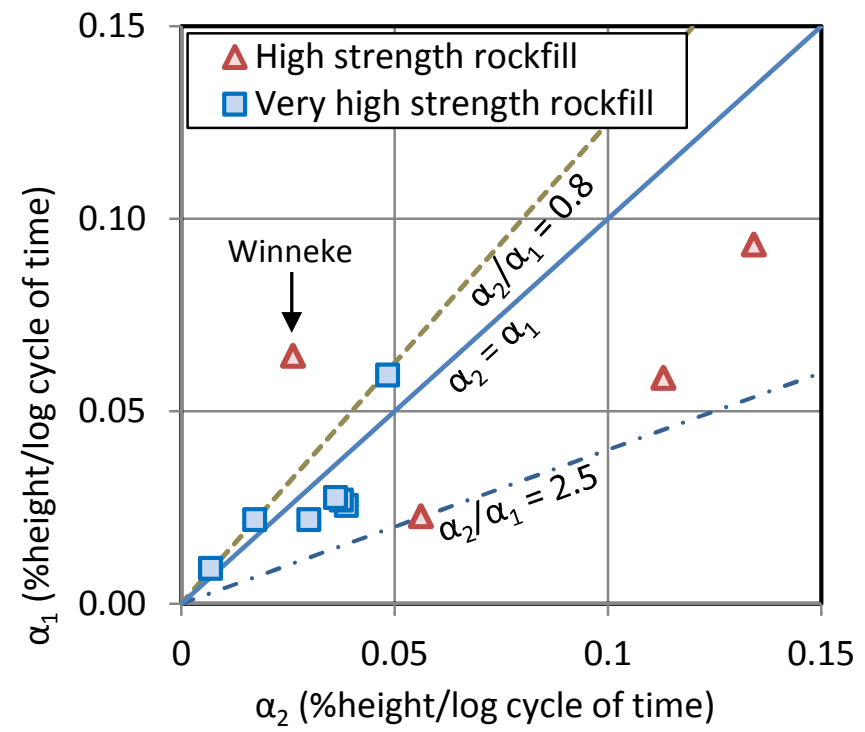

Fig. 13. Relative crest settlement rates before impoundment $\left(\alpha_{1}\right)$ vs. after impoundment $\left(\alpha_{2}\right)$ 


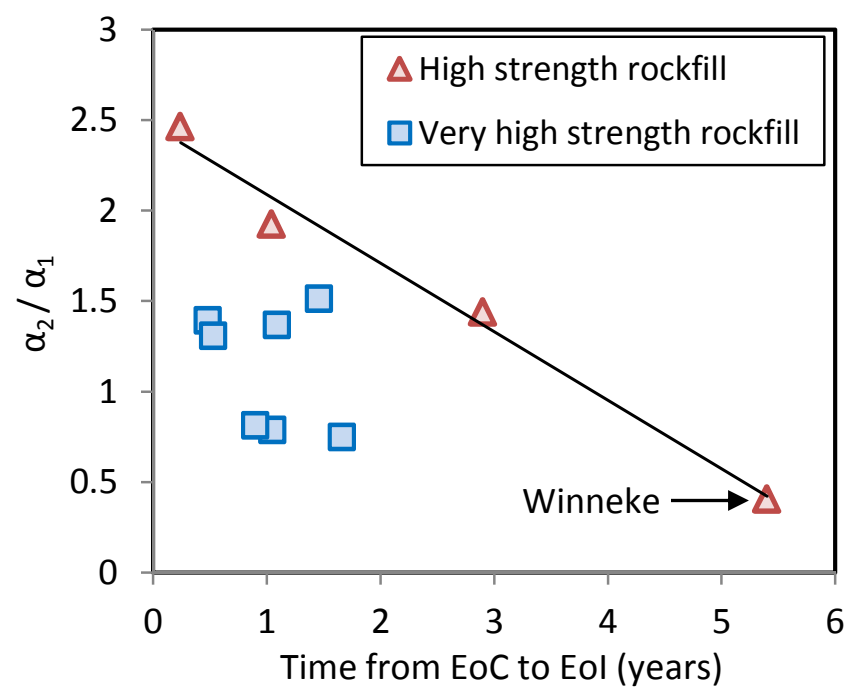

Fig. 14. The ratio of relative crest settlement rates after and before impoundment vs. time elapsed from the end of rockfill construction (EoC) to the end of impoundment (EoI)

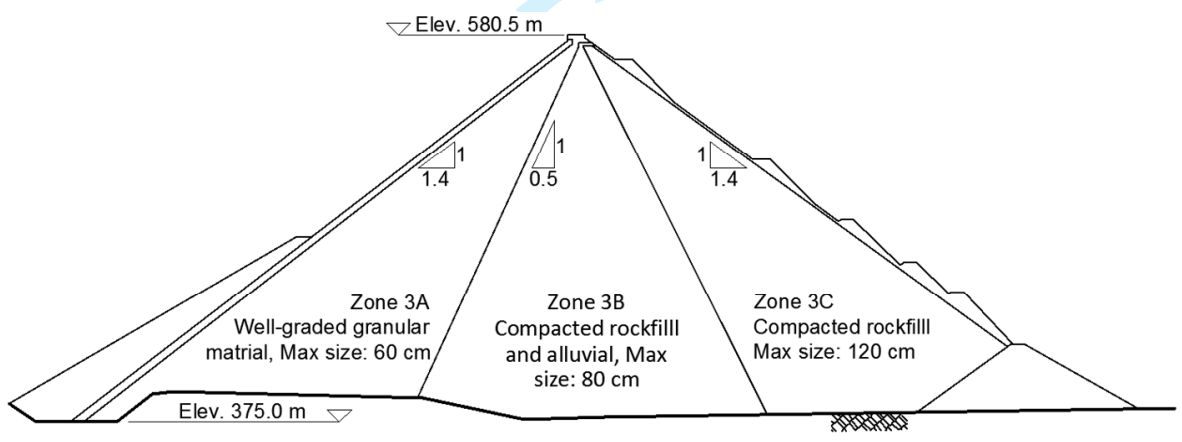

Fig. 15. Typical cross section of La Yesca dam(adapted from Marengo-Mogollón \& Rivera-Constantino 2012) 


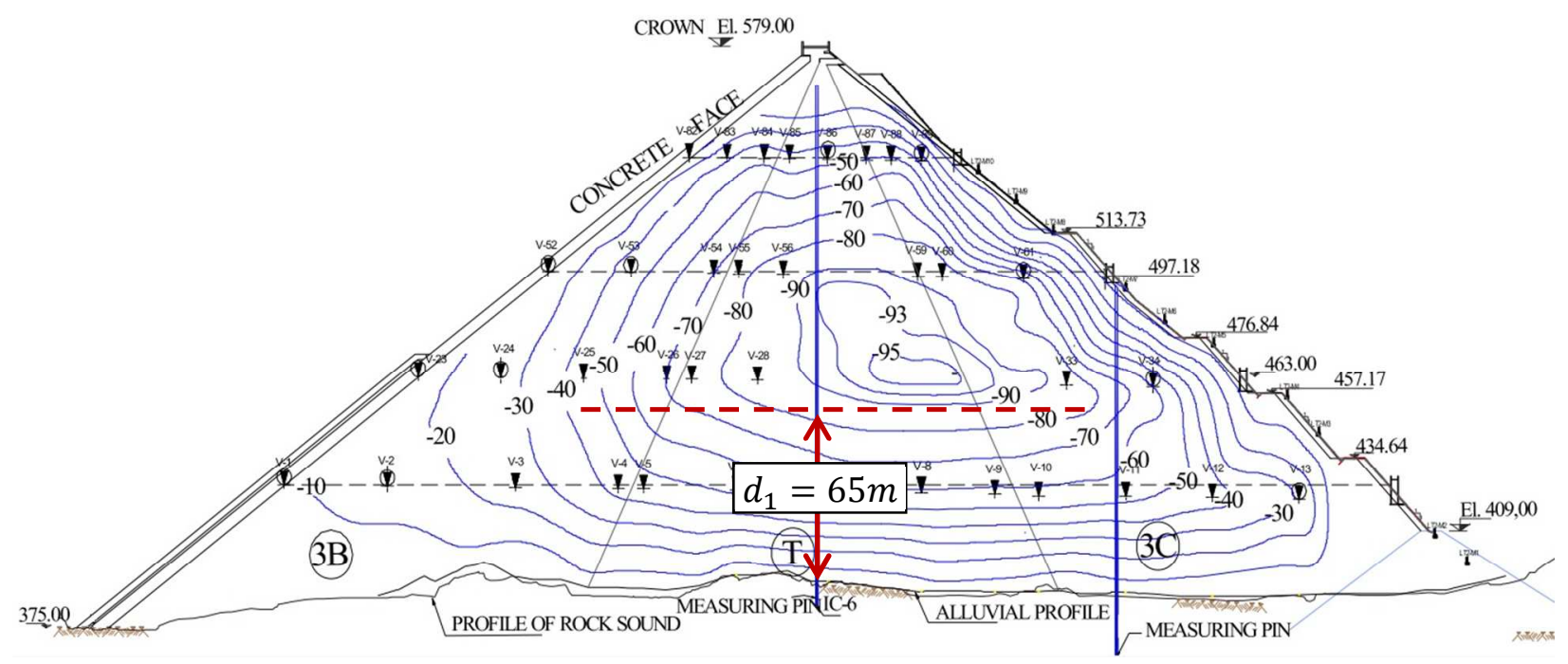

Fig. 16. Contours of settlements (cm) at La Yesca Dam for the end of construction (modified from Marengomogollón \& Rivera-Constantino, 2012)

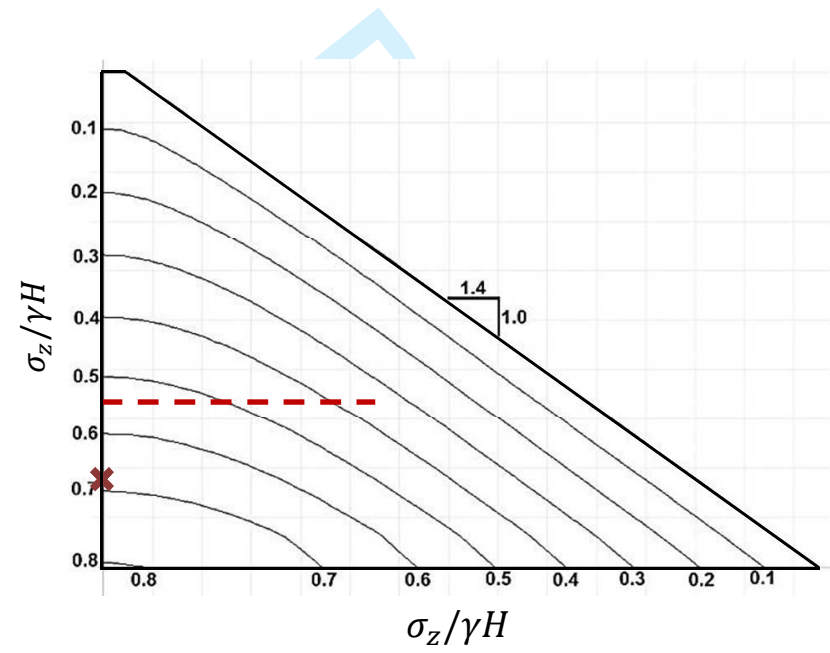

Fig. 17. Contours of vertical stress for a generic embankment with 1 horizontal to 1.4 vertical slope at end of construction $(\mathrm{H}=$ dam height in the section, and $\gamma=$ fill density) 


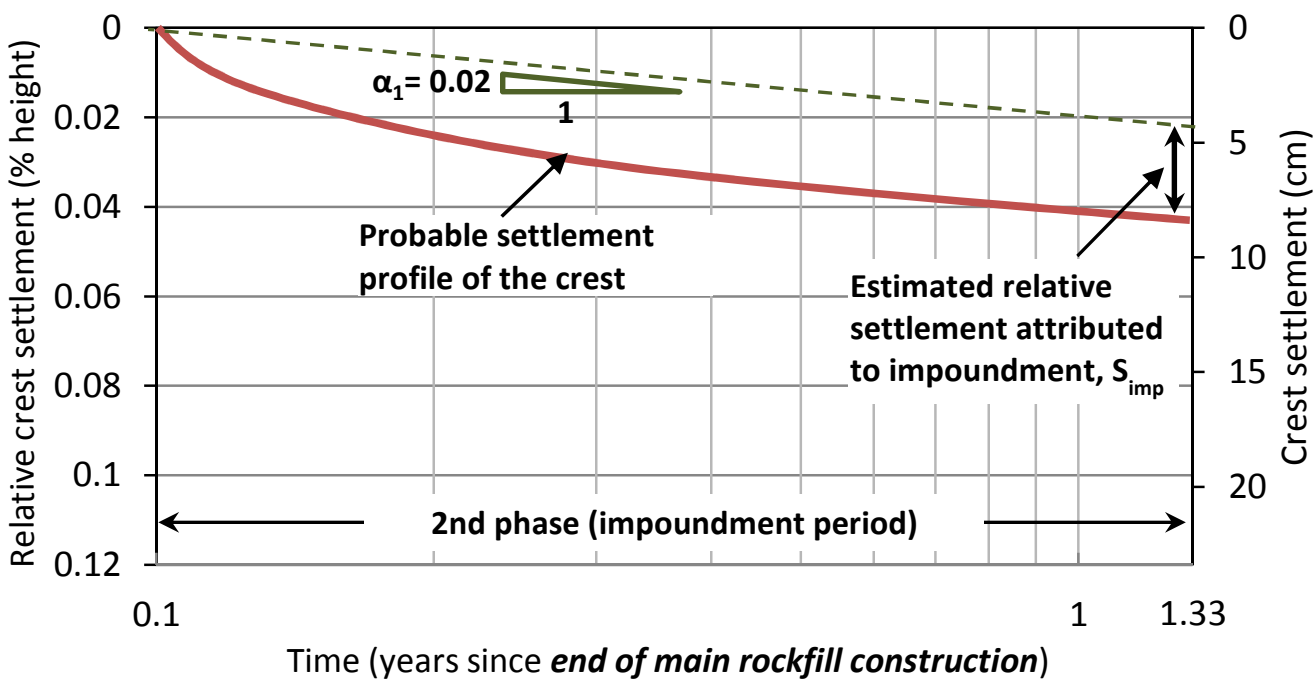

(a)

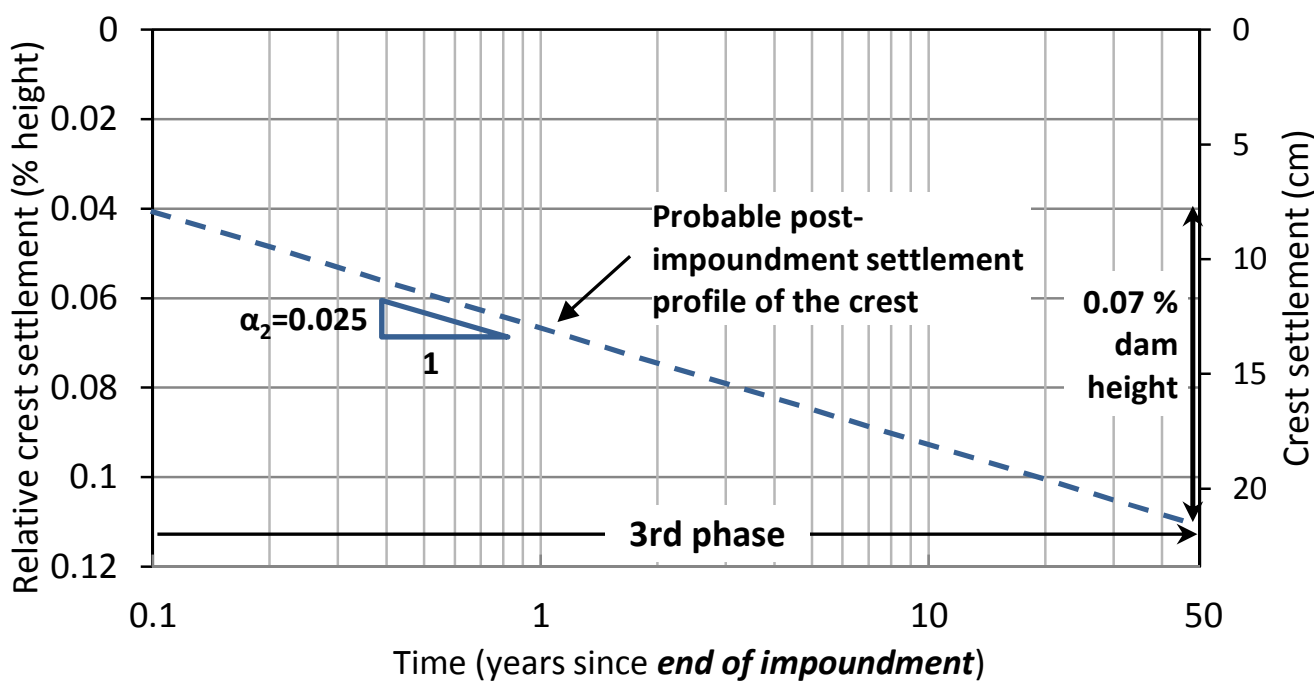

(b)

Fig. 18. Post-construction crest settlement prediction of La Yesca dam a) before and b) after the end of impoundment 


\section{Tables}

Table 1. Classification of unconfined compressive strength of rock according to Australian code: AS 17261993 (from Hunter and Fell 2002)

\begin{tabular}{ll}
\hline Strength Descriptor & UCS Range (MPa) \\
\hline Extremely High & $>240$ \\
Very High & 70 to 240 \\
High & 20 to 70 \\
Medium & 6 to 20 \\
\hline
\end{tabular}


Table 2. List of the studied CFRDs (data mostly from Hunter and Fell 2002)

\begin{tabular}{|c|c|c|c|c|c|c|c|c|c|c|}
\hline Dam's name & 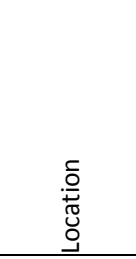 & 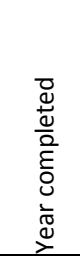 & 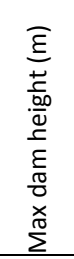 & 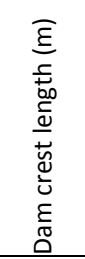 & 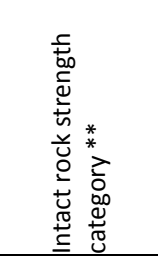 & 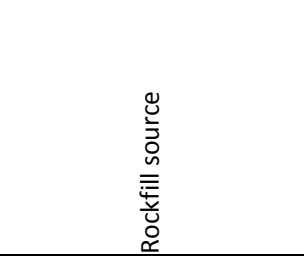 & 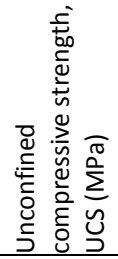 & 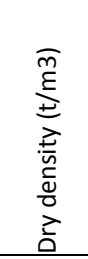 & 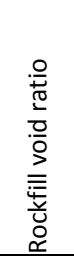 & 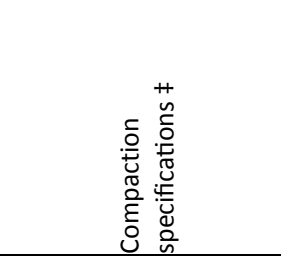 \\
\hline Bastyan & Tasmania & 1983 & 75 & 430 & EHS to VHS & Rhyolite & - & 2.2 & 0.23 & $20 \% \mathrm{~W} ; 1.0 \mathrm{~m} ; 8 \mathrm{p} 10 \mathrm{t}$ \\
\hline Cethana & Tasmania & 1971 & 110 & 213 & VHS & Quartzite & - & 2.07 & 0.27 & $15 \% \mathrm{~W} ; 0.9 \mathrm{~m} ; 4 \mathrm{p} 10 \mathrm{t}$ \\
\hline Foz Do Areia & Brazil & 1979 & 160 & 828 & HS to VHS & Basalt, Basaltic breccia & $185.5^{*}$ & 2.12 & 0.33 & $25 \% \mathrm{~W} ; 0.8 ; 4 \mathrm{p} 10 \mathrm{t}$ \\
\hline Murchison & Tasmania & 1982 & 94 & 200 & VHS & Rhyolite & 148 & 2.27 & 0.23 & $20 \% \mathrm{~W} ; 1.0 \mathrm{~m} ; 8 \mathrm{p} 10 \mathrm{t}$ \\
\hline Outardes 2 main dam & Canada & 1978 & 45.7 & 347.5 & VHS & Gneiss, Biotite & - & - & - & No $W ; 1.0 m ; 4 p 10 t$ \\
\hline Reece & Tasmania & 1986 & 122 & 374 & EHS to VHS & Dolerite & $225^{*}$ & 2.287 & 0.29 & $5-10 \% \mathrm{~W} ; 1.0 \mathrm{~m} ; 4 \mathrm{p} 10 \mathrm{t}$ \\
\hline Shuibuya & China & 2007 & 233 & 675 & VHS? & ? & - & 2.3 & 0.22 & $20 \% \mathrm{~W}$; ? ; ? \\
\hline Toulnustouc south dyke & Canada & 2004 & 46 & 400 & VHS & Gneiss & 118 & - & - & No $W ; 0.9 m ; 4 p 15 t$ \\
\hline Toulnustouc main dam & Canada & 2004 & 76 & 535 & VHS & Gneiss & 118 & - & - & No $W ; 0.9 m ; 4 p 15 t$ \\
\hline Kangaroo Creek & Australia & 1969 & 60 & 178 & MS to HS & Schist & 25 & 2.34 & 0.20 & $100 \% \mathrm{~W} ; 0.9 \mathrm{~m} ; 4 \mathrm{p} 10 \mathrm{t}$ \\
\hline Kotmale & Sri Lanka & 1984 & 90 & 560 & HS to VHS & Charnockitic/gneissic & - & 2.2 & - & $30 \% \mathrm{~W} ; 1.0 \mathrm{~m} ; 4 \mathrm{p} 15 \mathrm{t}$ \\
\hline Mackintosh & Tasmania & 1981 & 75 & 465 & MS to HS & Greywacke, some slate & 45 & 2.2 & 0.24 & $10 \% \mathrm{~W} ; 1.0 \mathrm{~m}, 8 \mathrm{p} 10 \mathrm{t}$ \\
\hline Mangrove Creek & Australia & 1981 & 80 & 380 & HS & Siltstone, sandstone & $49 *$ & 2.24 & 0.18 & $7.5 \% \mathrm{~W} ; 0.45 \mathrm{~m}, 4 \mathrm{p} 10 \mathrm{t}$ \\
\hline Serpentine & Tasmania & 1971 & 38 & 134 & $\mathrm{MS}$ to $\mathrm{HS}$ & Quartz schist & - & 2.1 & 0.26 & ? W; $0.6 \mathrm{~m} ; 4 \mathrm{p} 9 \mathrm{t}$ \\
\hline Tianshengqiao I & China & 1999 & 178 & 1168 & HS & Limestone, mudstone & $44^{*}$ & 2.2 & 0.21 & $? \mathrm{~W} ; 1.0 \mathrm{~m} ; 6 \mathrm{p} 15 \mathrm{t}$ \\
\hline White Spur & Tasmania & 1989 & 43 & 146 & HS to VHS ? & Tuff & - & 2.3 & 0.21 & $10 \% \mathrm{~W} ; 1.0 \mathrm{~m} ; 4 \mathrm{p} 10 \mathrm{t} ?$ \\
\hline Winneke & Australia & 1978 & 85 & 1050 & HS & Siltstone & 66 & 2.07 & 0.30 & $15 \% W ; 0.9 m ; 4-6 p 10 t$ \\
\hline Winscar $^{\dagger}$ & England & 1974 & 53 & 520 & HS? & Millstone Grit sandstone & - & 2.03 & 0.28 & $? \mathrm{~W} ; 1.7 \mathrm{~m} ; 4 \mathrm{p} 13.5 \mathrm{t}$ \\
\hline Xingo & Brazil & 1993 & 140 & 850 & HS to VHS? & Granite gneiss & - & 2.15 & - & $15 \% W ; 1.0 m ; 4-6 p 10 t$ \\
\hline
\end{tabular}

* Average of different zones of rockfill

** MS, HS, VHS and EHS stand for medium, high, very high and extremely high strength respectively

¥ Volumetric added water; layer thickness; number of passes and weight of roller respectively

+ Asphaltic concrete face rockfill dam 
Table 3. Calculated parameters for the studied CFRDs

\begin{tabular}{|c|c|c|c|c|c|}
\hline Dam's name & 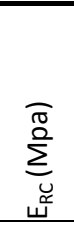 & 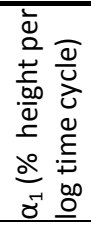 & 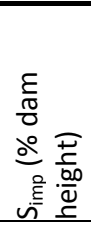 & 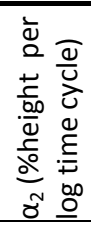 & 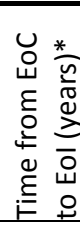 \\
\hline Bastyan & 130 & 0.022 & 0.016 & 0.017 & 1.05 \\
\hline Cethana & 137 & 0.027 & 0.036 & 0.038 & 0.48 \\
\hline Foz Do Areia & 47 & 0.059 & 0.031 & 0.048 & 0.90 \\
\hline Murchison & 190 & 0.022 & 0.013 & 0.030 & 1.09 \\
\hline Outardes 2 main dam & - & - & 0.015 & 0.017 & 0.15 \\
\hline Reece & 86 & 0.026 & 0.045 & 0.039 & 1.46 \\
\hline Shuibuya & 96.5 & - & 0.055 & 0.028 & 1.07 \\
\hline Toulnustouc south dyke & - & 0.009 & 0.015 & 0.007 & 1.66 \\
\hline Toulnustouc main dam & - & 0.028 & 0.079 & 0.037 & 0.53 \\
\hline Kangaroo Creek & - & - & - & 0.082 & - \\
\hline Kotmale & 61 & 0.059 & 0.090 & 0.113 & 1.04 \\
\hline Mackintosh & 45 & 0.093 & 0.115 & 0.134 & 2.90 \\
\hline Mangrove Creek & 55 & - & - & 0.285 & - \\
\hline Serpentine & 92 & - & 0.051 & 0.076 & 2.90 \\
\hline Tianshengqiao I & 43 & - & - & 0.140 & - \\
\hline White Spur & 180 & 0.023 & 0.013 & 0.056 & 0.24 \\
\hline Winneke & 55 & 0.064 & 0.084 & 0.026 & 5.40 \\
\hline Winscar & 17 & - & - & 0.175 & - \\
\hline Xingo & 34 & - & 0.203 & 0.163 & 1.46 \\
\hline
\end{tabular}

* EoC and Eol stand for: end of construction and end of impoundment 
Table 4. Hardening Soil model parameters used for modeling a generic embankment

\begin{tabular}{cccccccccccc}
\hline$\nu\left(\mathrm{kN} / \mathrm{m}^{3}\right)$ & $\begin{array}{c}\mathrm{E}_{50}^{\mathrm{ref}} \\
(\mathrm{MPa})\end{array}$ & $\begin{array}{c}\mathrm{E}_{\mathrm{oed}}^{\mathrm{ref}} \\
(\mathrm{MPa})\end{array}$ & $\begin{array}{c}\mathrm{E}_{\mathrm{ur}}^{\mathrm{ref}} \\
(\mathrm{MPa})\end{array}$ & $v_{\mathrm{ur}}$ & $\mathrm{p}^{\text {ref }}(\mathrm{kPa})$ & $\mathrm{R}_{\mathrm{f}}$ & $\mathrm{m}$ & $\mathrm{c}(\mathrm{kPa})$ & $\varphi(\mathrm{deg})$ & $\psi(\mathrm{deg})$ & $\mathrm{K}_{0}^{\mathrm{nc}}$ \\
\hline 23 & 100 & 100 & 300 & 0.2 & 100.0 & 0.9 & 0.5 & 0.0 & 45 & 10 & 0.5 \\
\hline
\end{tabular}

Table 5. Summary of predicted parameters for La Yesca dam

\begin{tabular}{|c|c|c|c|c|c|c|}
\hline \multirow[t]{2}{*}{$\begin{array}{l}\text { Parameter used } \\
\text { for prediction }\end{array}$} & \multirow[t]{2}{*}{$\begin{array}{l}\alpha_{1}(\% \text { per log } \\
\text { cycle of time) }\end{array}$} & \multirow{2}{*}{$\begin{array}{l}\text { Time-dependent } \\
\text { settlement during } \\
\text { impoundment } \\
\text { (cm) }\end{array}$} & \multicolumn{2}{|c|}{$\begin{array}{l}\text { Settlement } \\
\text { attributed to impoundment }\end{array}$} & \multicolumn{2}{|c|}{$\begin{array}{l}\text { Settlement } \\
\text { after impoundment }\end{array}$} \\
\hline & & & $\begin{array}{l}\mathrm{S}_{\mathrm{imp}}(\% \text { dam } \\
\text { height) }\end{array}$ & $(\mathrm{cm})$ & $\begin{array}{l}\alpha_{2}(\% \text { per } \\
\text { log cycle of } \\
\text { time) }\end{array}$ & $\begin{array}{l}\text { ( } \mathrm{cm} \text { in } 50 \\
\text { years) }\end{array}$ \\
\hline Dam height & 0.055 & 12 & 0.05 & 10 & 0.052 & 27.5 \\
\hline Rockfill modulus & 0.02 & 4.5 & 0.02 & 4 & 0.025 & 13.5 \\
\hline
\end{tabular}

